\title{
Batólito Guaporeí: uma extensão do Complexo Granitoide Pensamiento em Mato Grosso, SW do Cráton Amazônico
}

\author{
The Guaporeí Batholith: an extension of the Pensamiento Granitoid \\ Complex in Mato Grosso, SW Amazonian Craton
}

\author{
Patrícia Alves Nalon ${ }^{1,4 *}$, Maria Zélia Aguiar de Sousa ${ }^{1,2,4,6}$, \\ Amarildo Salina Ruiz ${ }^{1,3,4,6}$, Moacir José Buenano Macambira ${ }^{5,6}$
}

RESUMO: O Batólito Guaporeí é um corpo de aproximadamente $240 \mathrm{~km}^{2}$ alongado segundo a direçáo NW, localizado na regiáo de Vila Bela da Santíssima Trindade, estado de Mato Grosso. Situa-se nos domínios da Província Rondoniana-San Ignácio, no Terreno Paraguá, na porção meridional do Cráton Amazônico. É formado por monzogranitos e, subordinadamente, granodioritos, quartzo-monzonitos e sienogranitos, caracterizados por granulaçâo grossa e textura, em geral, porfirítica a porfiroclástica. Possui biotita como mineral máfico primário, por vezes, associada a anfibólio, e encontra-se metamorfizado na fácies xisto verde, exibindo estrutura milonítica, em estreitas zonas de cisalhamento. Evidências geoquímicas indicam que essas rochas derivam de um magma cálcio-alcalino de alto potássio a shoshonítico, metaluminoso a levemente peraluminoso evoluído por cristalizaçáo fracionada associada à assimilaçáo crustal, possivelmente gerado em ambiente de arco continental. Duas fases de deformação relacionadas à Orogenia San Ignácio, caracterizadas pelo estiramento e alinhamento mineral evidenciadas pelas foliaçôes $S_{1}$ e $S_{2}$, foram identificadas nestas rochas. Foi obtida pelo método de evaporaçấo de $\mathrm{Pb}$ em zircão uma idade de $1.314 \pm 3 \mathrm{Ma}$, interpretada como idade de cristalizaçăo do corpo granítico. Dados $\mathrm{Sm}-\mathrm{Nd}$ em rocha total indicam idade modelo $\mathrm{T}_{\mathrm{DM}}$ em torno de $1,7 \mathrm{Ga}$ e valor negativo para $\varepsilon_{\mathrm{Nd}(\mathrm{t}=1,3)}(-14)$, corroborando a hipótese de envolvimento crustal na gênese do magma. Os resultados obtidos apontam semelhanças entre essas rochas e aquelas de regiâo adjacente em território boliviano, sugerindo que o Granito Guaporeí representa uma extensão do Complexo Granitoide Pensamiento.

PALAVRAS-CHAVE: Batólito Guaporeí; Complexo Granitoide Pensamiento; Terreno Paraguá; Cálcio-alcalino de alto K.

\begin{abstract}
The Guaporei Batholith is located in the Vila Bela da Santissima Trindade region, at Mato Grosso State (Brazil), and crops out over $240 \mathrm{~km}^{2}$ along the NW direction. It is situated in the Paragua Terrane, included in the Rondonian-San Ignacio Province, in the southwestern portion of the Amazonian Craton. The batholith is made up of monzogranite, with subordinate granodiorite, quartz monzonite and syenogranite, shows coarse porphyriticl porphyroclastic texture, is metamorphosed in the greenschist facies and mylonitized along shear zones. The biotite is the main primary mafic mineral, sometimes associated with amphibole. Geochemical data indicated high-potassium calc-alkaline and metaluminous to peraluminous character, probably generated in continental arc environment, and evolved by fractional crystallization associated to crustal assimilation. Two stages of deformation related to the evolution of San Ignacio compressional orogeny were identified and are characterized by stretching and lineation, and development of $S_{i}$ and $S_{2}$ foliations. Dating by single zircon Pb-evaporation method yields a crystallization age of $1,314 \pm 3 \mathrm{Ma}$, whereas $S m-N d$ whole rock isotope data indicate a $T_{D M}$ model age of $c a .1 .7 \mathrm{Ga}$ and a negative value for $\varepsilon_{N d(t=1,3)}$ of -14 , suggesting crustal contribution in the magma genesis. The obtained data indicate similarities between these rocks and those of the Pensamiento Granitoid Complex, in the Bolivian counterpart, and put in evidence that the Guaporei Batholith is an extension of this complex.
\end{abstract}

KEYWORDS: Guaporeí Batholith; Pensamiento Granitoid Complex; Paraguá Terrane; High-K calc-alkaline.

\footnotetext{
${ }^{1}$ Programa de Pós-Graduação em Geociências, Instituto de Ciências Exatas e da Terra - ICET, Universidade Federal de Mato Grosso - UFMT, Cuiabá (MT), Brasil E-mail:nalonp@gmail.com

${ }^{2}$ Departamento de Recursos Minerais, Instituto de Ciências Exatas e da Terra - ICET, Universidade Federal de Mato Grosso - UFMT, Cuiabá (MT), Brasil. E-mail:prof.mzaguiar@gmail.com

32Departamento de Geologia Geral, Instituto de Ciências Exatas e da Terra - ICET, Universidade Federal de Mato Grosso - UFMT, Cuiabá (MT), Brasil. E-mail: asruiz@gmail.com ${ }^{4}$ Grupo de Pesquisa em Evolução Crustal e Tectônica - Guaporé, Universidade Federal de Mato Grosso - UFMT, Cuiabá (MT), Brasil.

${ }^{5}$ Laboratório de Geologia Isotópica (Pará-Iso), Instituto de Geociências - IG, Universidade Federal do Pará - UFPA, Belém (PA), Brasil. E-mail: moamac@ufpa.br ${ }^{6}$ Instituto Nacional de Ciência e Tecnologia de Geociências da Amazônia - GEOCIAM, Universidade Federal do Pará - UFPA, Belém (PA), Brasil. *Autora correspondente

Manuscrito ID 27726. Recebido em: 20/06/2012. Aprovado em: 24/10/2012
} 


\section{INTRODUÇÃO}

Litherland et al. (1986) descreveram em território boliviano um expressivo e volumoso magmatismo de natureza plutônica ácida, cujas idades variam de 1,37 Ga a 1,30 Ga. Tais granitoides foram agrupados sob a designação Complexo Granitoide Pensamiento e classificados, conforme o momento de sua colocação em relação ao pico metamórfico e deformacional da Orogenia San Ignácio, como sin a pós-cinemáticos. Na região de Vila Bela da Santíssima Trindade, sudoeste do estado de Mato Grosso, aflora a porção extremo oriental do Terreno Paraguá, limitada a leste pelo Terreno Rio Alegre (Fig. 1). Entre as unidades litoestratigráficas que constituem esse terreno nessa regiáo, destacam-se um embasamento gnáissico com idade de $1.651 \pm 4$ ( $\mathrm{Pb}-\mathrm{Pb}$ por evaporação em zircão; Figueiredo et al. 2009), que serve de encaixante para o Granito Guaporeí, além de plugs e diques do Granito Passagem (Jesus et al. 2010), ambos correlacionados ao Complexo Granitoide Pensamiento (Nalon et al. 2009). $\mathrm{Na}$ área estudada, o Grupo Aguapeí não apresenta deformação dúctil e metamorfismo e repousa em discordância erosiva sobre os gnaisses e granitoides. O propósito deste trabalho foi caracterizar o Batólito Guaporeí do ponto de vista petrográfico, estrutural e geoquímico, definir sua idade e seu significado petrológico. Buscou-se, além disso, avaliar se ele representa uma extensão do Complexo Granitoide Pensamiento em território brasileiro ou se constitui uma intrusão independente.

\section{CONTEXTO GEOLÓGICO REGIONAL}

A área de estudo está localizada na região de Vila Bela da Santíssima Trindade - Mato Grosso, contida na Província Rondoniana-San Ignácio e inserida no Terreno Paraguá (Ruiz 2009 e Bettencourt et al. 2010; Fig. 1), na porção meridional do Cráton Amazônico. Este terreno é uma unidade tectônica complexa, anteriormente denominada de Cráton Paraguá (Litherland et al. 1986) e ultimamente descrita como um fragmento crustal alóctone, acrescido à margem do proto-cráton Amazônico durante o Mesoproterozoico ou Neoproterozoico (Boger et al. 2005). Segundo os autores mencionados, a colisão e aglutinação do Terreno Paraguá ao Cráton Amazônico teria ocorrido durante a orogenia Sunsás (1,0 a 0,9 Ga), enquanto Ruiz (2005, 2009) e Bettencourt et al. (2010) sugeriram que se deu durante a Orogenia San Ignácio $(1,37$ a 1,3 Ga). Esse terreno é constituído por um embasamento paleoproterozoico, representado pelo Complexo Lomas Maneches, Grupo de Xistos San Ignácio e Complexo
Gnáissico Chiquitania, e por granitoides cálcio-alcalinos mesoproterozoicos (Complexo Granitoide Pensamiento). Informações adicionais sobre a cronoestratigrafia desse terreno foram apresentadas por Boger et al. (2005), com base em dataçôes pelo método U-Pb em zircão (SHRIMP) de rochas do Complexo Lomas Maneches e do Complexo Gnáissico Chiquitania. Matos et al. (2009) sugeriram a seguinte sequência litoestratigráfica: Complexo Chiquitania (1,79 Ga), Grupo San Ignácio (< 1,76 Ga), Suíte Lomas Maneches (1,68 Ga) e Complexo Granitoide Pensamiento.

O Complexo Granitoide Pensamiento compreende grande extensão areal de rochas graníticas e gnáissicas que guardam os registros metamórficos e deformacionais da Orogenia San Ignácio, de 1,40 - 1,28 Ga (Bettencourt et al. 2010). Os corpos do complexo foram subdivididos por Litherland et al. (1986) em sin a tardicinemáticos e tardi a pós-cinemáticos. Os corpos sin a tardicinemáticos $(1.373-1.347 \mathrm{Ma})$ caracterizam-se por apresentar rochas porfiríticas e foliadas e os tardi a pós-cinemáticos $(1.340 \mathrm{Ma})$ exibem rochas de granulação fina sem foliação marcante.

A litoestratigrafia do Terreno Paraguá na região de Vila Bela da Santíssima Trindade foi definida por Nalon (2010) e Figueiredo (2010) e compreende as seguintes unidades: Ortognaisse Turvo, Granito Fronteira, Complexo Metamórfico Ricardo Franco, Gnaisse Shangrilá, Complexo Granitoide Pensamiento (granitos Passagem e Guaporeí), Suíte Intrusiva Guará, Granito Vila Bela, Grupo Aguapeí e Suíte Intrusiva Huanchaca (Fig. 2).

\section{GEOLOGIA E PETROGRAFIA}

O Batólito Guaporeí é constituído por granitos anisotrópicos com foliação bem marcada ou, localmente, incipiente, caracterizada pelo estiramento e orientação preferencial de minerais félsicos e arranjo planar dos máficos que, quando situados próximos a zonas de cisalhamento, encontram-se milonitizados. Essas rochas configuram um corpo de aproximadamente $240 \mathrm{~km}^{2}$ limitado por zonas de cisalhamento que o colocam a NE, parcialmente, em contato com o Gnaisse Shangri-lá e Complexo Metamórfico Ricardo Franco (Figueiredo 2010), e a SW com o Gnaisse Turvo (Figueiredo 2010; Fig. 2).

Suas exposiçôes típicas correspondem a lajedos de dimensóes decamétricas, blocos e matacóes subarredondados (Figs. 3A e B), por vezes, cortados por veios e vênulas centimétricas de composição quartzo-feldspática e por diques do Granito Passagem (Fig. 3C). As rochas dessa unidade apresentam cores claras que variam de branco-acinzentado a rosa-avermelhado e textura dominantemente porfirítica/porfiroclástica (Fig. 3D), com fenocristais 
centimétricos de feldspato alcalino em matriz de granulação média. De forma subordinada, encontram-se litotipos de granulação fina e cor branca a cinza-esverdeada. De acordo com o diagrama QAP (Fig. 4; Streckeisen 1976), são hornblenda-biotita ou biotita-monzogranitos, com sienogranitos, granodioritos e quartzo-monzonitos subordinados. Caracteristicamente, a maioria das rochas desta unidade exibe fenocristais de feldspato alcalino rosa a branco, por vezes estirados, imersos em uma matriz composta por quartzo, feldspato alcalino e plagioclásio, biotita e, às vezes, hornblenda.

Ao microscópio, as rochas estudadas apresentam textura porfirítica a porfiroclástica com fenocristais de feldspatos alcalinos, plagioclásio e quartzo em uma matriz de mesma composição, por vezes, recristalizada. A biotita e, quando presente, o anfibólio ocorrem em cristais isolados ou em agregados isorientados. A paragênese acessória primária está representada por allanita, titanita, apatita,

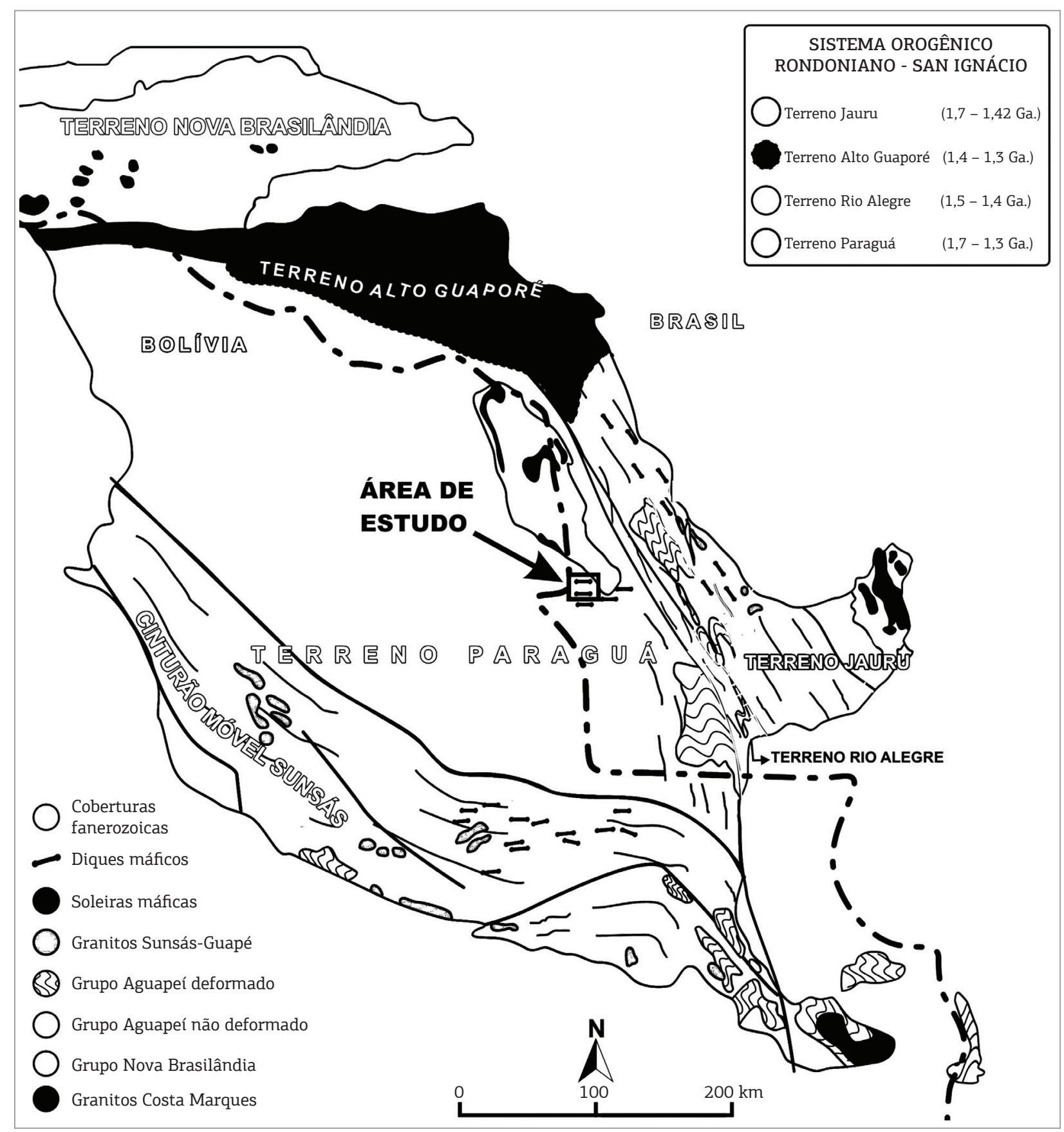

Figura 1. Localização da área estudada no mapa tectônico do SW do Cráton Amazônico em Mato Grosso, Rondônia, e oriente da Bolívia (Ruiz 2009). 


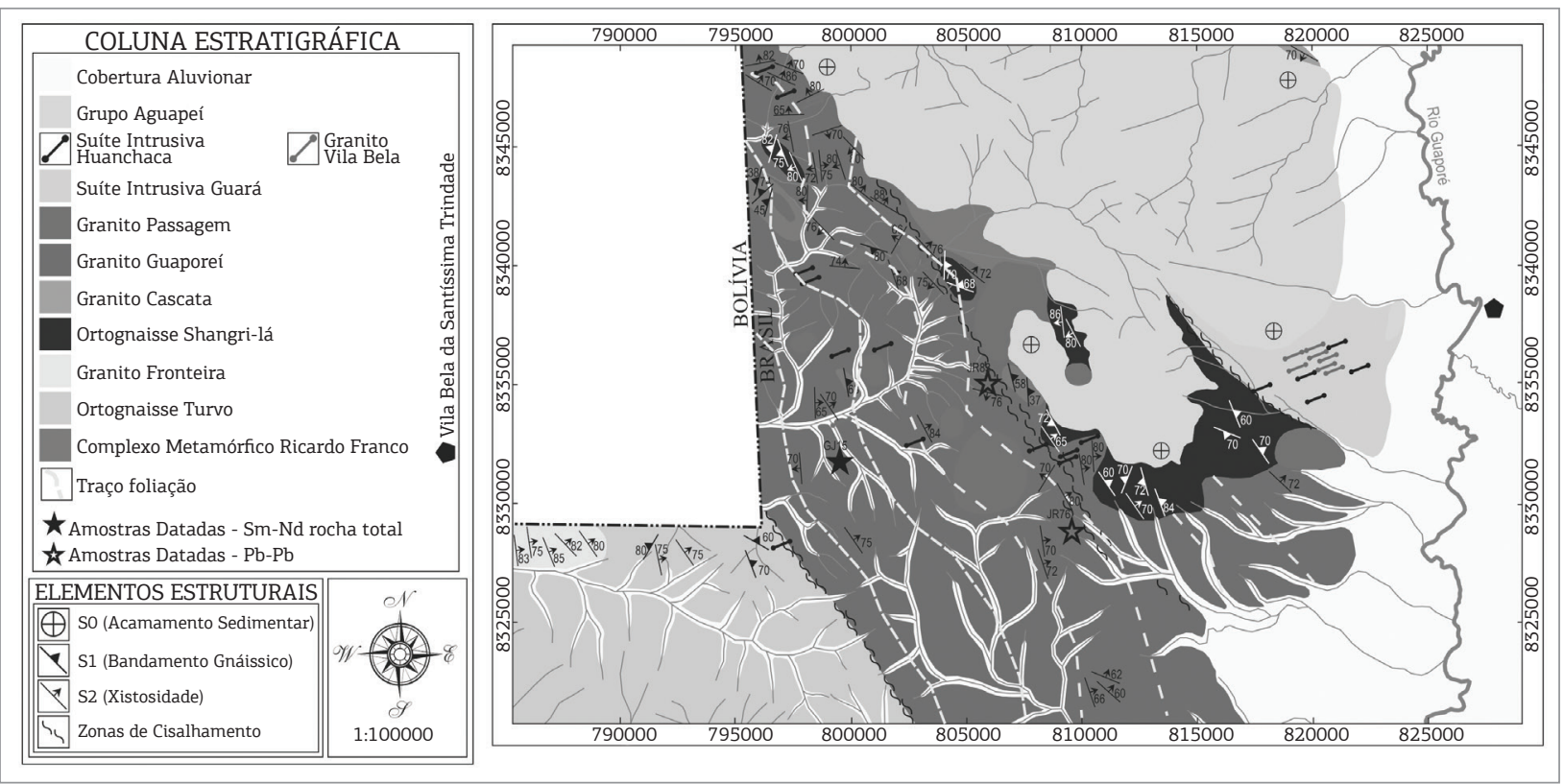

Figura 2. Mapa geológico do Terreno Paraguá na região de Vila Bela da Santíssima Trindade (MT).
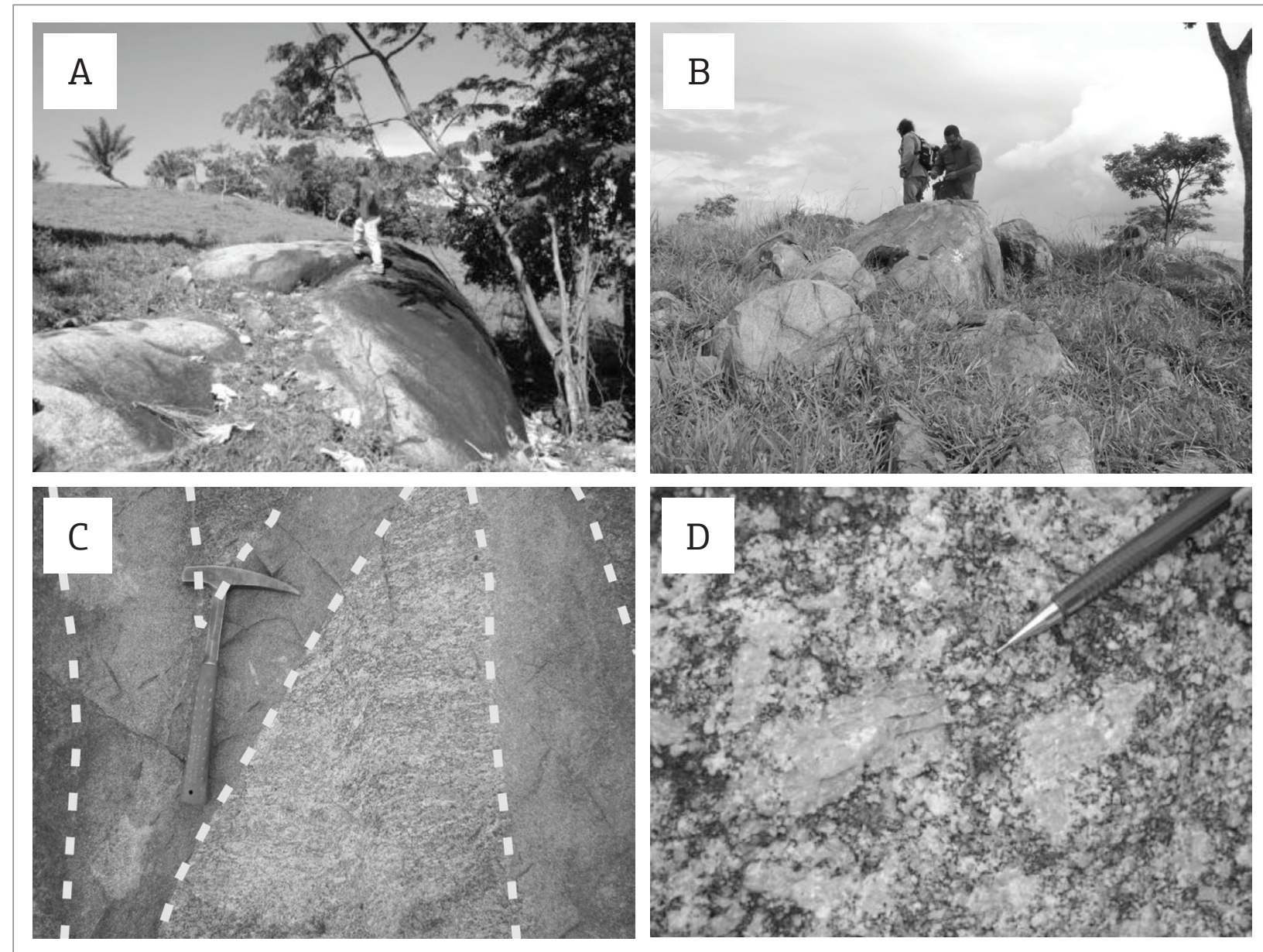

Figura 3. Ilustrações de afloramentos e de amostra de mão do Batólito Guaporeí: (A) ocorrência em lajedo; (B) matacões e blocos subarredondados; (C) dique do Granito Passagem cortando o Guaporeí; (D) aspecto macroscópico, com rocha porfirítica formada por fenocristais centimétricos de feldspato alcalino em matriz inequigranular média. 
zircão, monazita, rutilo e opacos; clorita, sericita, epidoto, clinozoizita, argilo-minerais e opacos constituem os produtos de alteração ou fases de metamorfismo de baixo grau da fácies xisto verde. Quando em zonas de cisalhamento, a trama dessas rochas configura feiçóes típicas de milonitização resultantes de mecanismos de deformação, como recristalização dinâmica e deformação intracristalina. Os litotipos deformados mais intensamente podem ser classificados como protomilonitos e, mais restritamente, como ultramilonitos, caracterizados por cerca de 40 e $80 \%$ de matriz, respectivamente (Sibson 1977).

Os feldspatos alcalinos formam fenocristais e porfiroclastos e se apresentam, principalmente, em grãos anédricos com bordas cominuídas e exibem geminações em grade (dupla macla albita + periclina) e do tipo Carlsbad. Em geral, apresentam intercrescimentos pertíticos, com lamelas sódicas tanto em grãos/gotas quanto em filmes e flâmulas (Fig. 5A), e podem formar intercrescimentos granofíricos com o quartzo. Às vezes, observam-se porfiroclastos de prováveis cristais de ortoclásio primário que ainda preservam a macla Carlsbad original, porém com igual presença de geminação em grade incipiente, sugerindo sua microclinização. Os feldspatos alcalinos da matriz se apresentam em grãos anédricos, provenientes de recristalização, que exibem geminação em grade. Evidências de processos de alteração, como argilização e sericitização, são comuns. Os plagioclásios dispóem-se como porfiroclastos anédricos a subédricos (Fig. 5B) ou em pequenos grãos recristalizados, compondo a matriz com geminaçóes polissintéticas do tipo albita e/ou periclina. Apresentam, por vezes, textura mirmequítica e, em algumas amostras, encontram-se intensamente turvos em decorrência dos processos

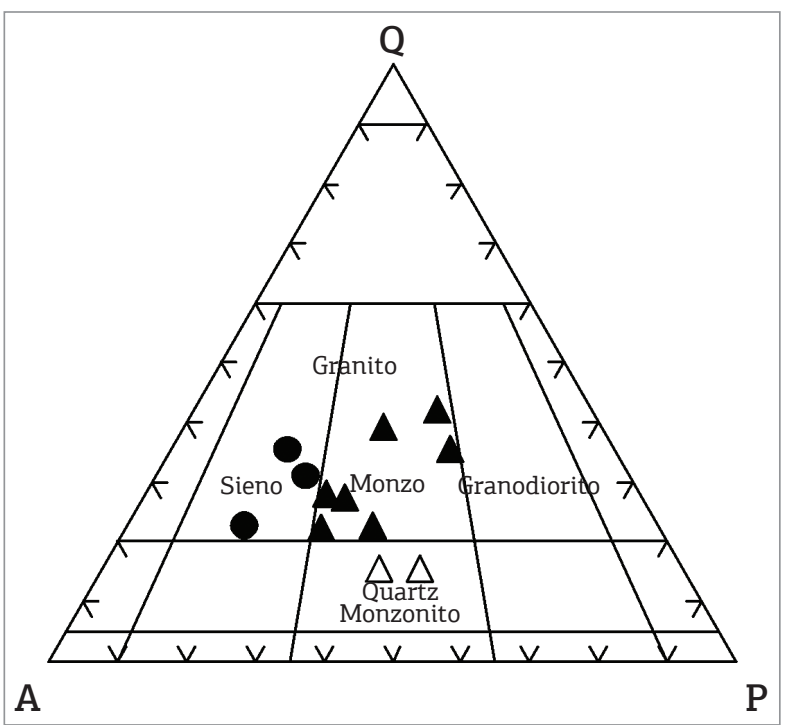

Figura 4. Diagrama QAP para as rochas do Batólito Guaporeí (campos conforme Le Maitre et al. 2002). pós-magmáticos, como sericitização, argilização e saussuritização com grande quantidade de epidoto/clinozoizita, sericita e calcita. O quartzo ocorre em subgrãos anédricos e em cristais poligonais formando textura em mosaico (Fig. 5C), bem como na forma de grãos finos que constituem a matriz recristalizada que envolve os porfiroclastos de feldspatos. Deformação intracristalina é evidenciada principalmente nas rochas milonitizadas (Fig. 5D) pela formação de ribbons (Fig. 5E), extinção ondulante, lamelas e bandas de deformação e recristalização em subgrãos que, por vezes, exibem feição tabuleiro de xadrez. A biotita apresenta-se em palhetas milimétricas anédricas a subédricas, com pleocroísmo castanho-claro a marrom-escuro e, por vezes, deformadas, em agregados com clorita, epidoto e opacos. Também é observada em lamelas isoladas ou inclusas nos feldspatos alcalinos, associada ao anfibólio, podendo representar produto de transformação deste último. Encontra-se, em geral, substituída parcial a totalmente por clorita de coloração verde-claro, caracterizada como peninita (Fig. 5F) e, localmente, por cristais fibrosos de muscovita. O anfibólio, identificado como hornblenda, ocorre em cristais subédricos (Fig. 5G) ou anédricos, formando agregados com biotita e opacos. Apresenta pleocroísmo intenso que varia de verde-amarronzado a verde-escuro, exibindo, por vezes, discreta zonação e textura poiquilítica com quartzo. Exibe ainda transformação em biotita e/ou clorita principalmente nas bordas, nos traços de clivagens e fraturas. A titanita está presente em duas geraçôes, sendo uma primária formada por cristais de hábito romboédrico, com frequência inclusa nos feldspatos, e outra definida por grãos secundários subédricos a anédricos, poiquiloblásticos (Fig. 5H). Localmente, é resultante de processo de substituição dos minerais óxidos de Fe e Ti ocorrendo em torno do mineral opaco, possivelmente ilmenita, caracterizando textura coronítica. A allanita se apresenta em cristais subédricos de cor amarelo-alaranjada, às vezes zonados ou de aspecto isotrópico por ter sido sua estrutura parcialmente destruída por causa de processo de metamictização. Outros minerais do grupo do epidoto acham-se disseminados ou concentrados nos grãos de plagioclásio, associados à sericita e calcita, provenientes de saussuritização. O zircão é uma fase acessória comum, ocorrendo em minúsculos cristais euédricos a anédricos, prismáticos, dispersos na matriz ou inclusos, preferencialmente, na biotita onde desenvolvem halos pleocroicos. A apatita ocorre com hábito acicular, inclusa nos feldspatos e na allanita ou disseminada na matriz. Os minerais opacos apresentam-se em cristais euédricos a anédricos, localmente dendríticos, pretos ou com tonalidades amareladas a avermelhadas, ocorrendo isolados ou interdigitados com máficos, por vezes, como produto de sua alteração. São observados também, parcialmente alterados, 

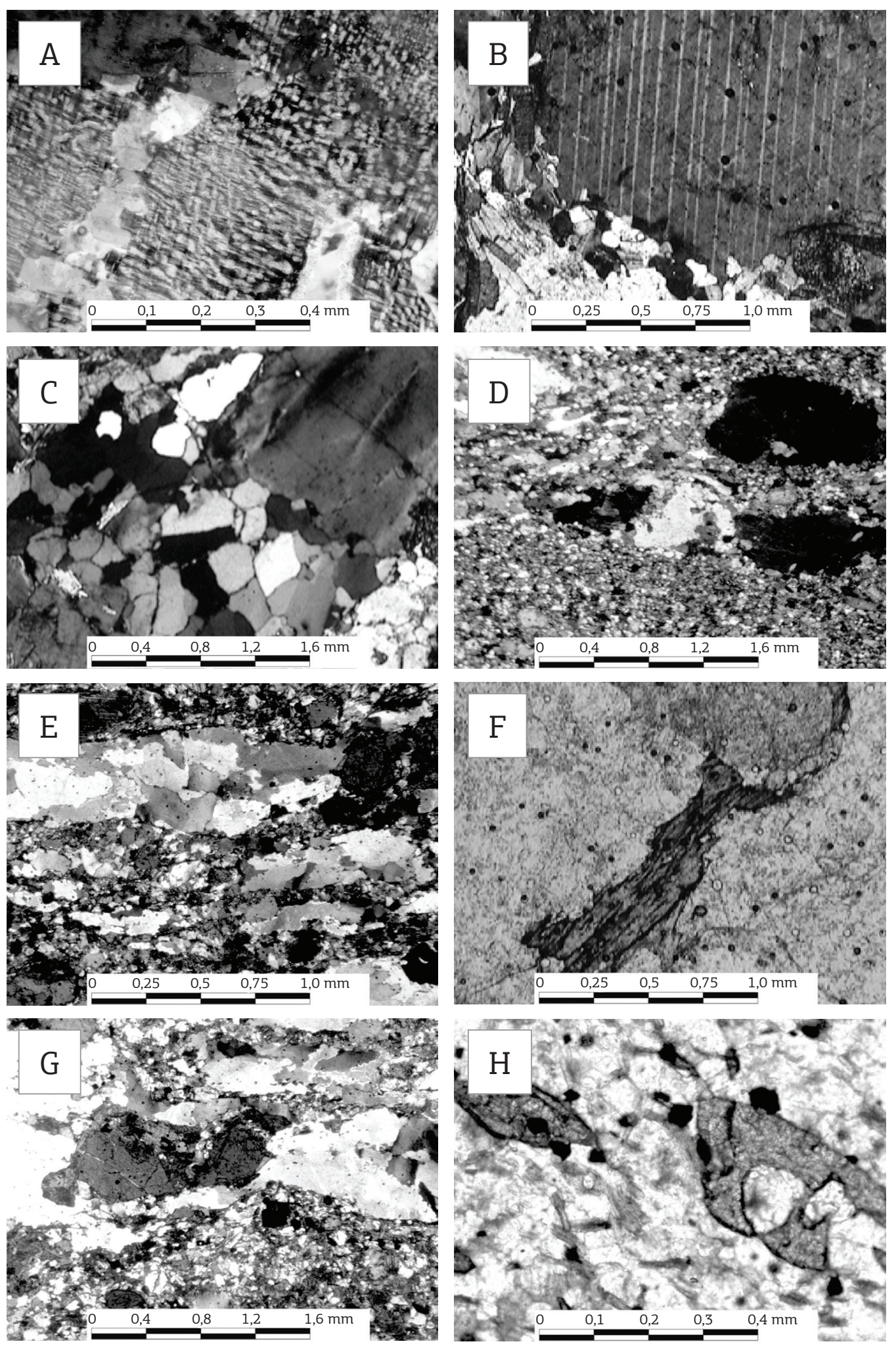

Figura 5. Fotomicrografias de rochas do Batólito Guaporeí ilustrando: (A) feldspato alcalino anédrico com intercrescimento pertítico do tipo flâmula e gotas; (B) parte de porfiroclasto de plagioclásio com bordas cominuídas formadas por minúsculos subgrãos de feldspatos e quartzo neocristalizados associados a palhetas orientadas de biotita; (C) agregado de grãos de quartzo em mosaico com junções tríplices de $120^{\circ}$ e porfiroclasto de quartzo com extinção ondulante; (D) ultramilonito com matriz fina recristalizada e ribbons de quartzo; (E) quartzo fitado com subgrãos em matriz quartzo-feldspática recristalizada; $(F)$ palheta de biotita parcialmente transformada em clorita; $(G)$ grão anédrico de hornblenda orientado segundo a foliação marcada por ribbons de quartzo; $(H)$ cristais subédricos de titanita poiquiloblástica. Polarizadores cruzados em A, B, C, D, E e G e paralelos em F e H. 
originando titanita, biotita, clorita e rutilo. O rutilo representa geralmente um produto de alteraçáo da ilmenita e da titanita, sendo encontrado associado a esses minerais ou, muitas vezes, à clorita, exibindo hábito fibroso a acicular.

\section{CARACTERIZAÇÃO ESTRUTURAL}

$\mathrm{Na}$ área estudada, foi identificada a atuação de duas fases de deformação, $F_{1}$ e $F_{2}$, correspondentes a fase $D_{3}$ da orogenia San Ignácio (Litherland et al. 1986). A fase $\mathrm{D}_{3}$ é reconhecida como o último e maior evento penetrativo, sendo simultânea à colocação de volumosas intrusôes graníticas sincinemáticas e migmatização nas rochas do Terreno Paraguá. Nas rochas do Batólito Guaporeí, a fase de deformação $\mathrm{F}_{1}$ é de natureza dúctil, sendo representada pelo desenvolvimento de uma foliação regional penetrativa $\left(S_{1}\right)$, lineação mineral e de estiramento $\left(l_{1}\right)$, e zonas de cisalhamento estreitas subparalelas à foliação regional $\left(S_{1}\right)$. A foliação $S_{1}$ é definida como uma xistosidade marcada pela orientação preferencial da matriz quartzo-feldspática e dos porfiroclastos de feldspato alcalino. Os máficos, principalmente a biotita e, em menor proporção, o anfibólio, completam a trama planar penetrativa (Fig. 6). A xistosidade $S_{1}$ é observada ao longo de todo o Batólito, no entanto a sua orientação varia de $\mathrm{N} 30-45 \mathrm{~W} / 65-80 \mathrm{NE}$ em sua porção central e sul e para N75 - 65SE/70 - 80NW no setor norte (Fig. 7).

Zonas de cisalhamento reversas, paralelas a $S_{1}$, foram reconhecidas nas bordas e no interior do Batólito. Formam estreitas e contínuas faixas, com desenvolvimento expressivo de proto a ultramilonitos, ou, mais comumente, milonitos com a textura ocelar típica. Lineação de estiramento e mineral $\mathrm{l}_{1}$ down dip a levemente oblíqua, e os porfiroclastos de feldspato alcalino rotacionados, indicam um movimento de topo de NE para SW.

Em análise microscópica nos sieno e monzogranitos, a foliação $S_{1}$ é marcada principalmente pelo alinhamento de minerais máficos (Fig. 8A). Nas rochas quartzo-monzoníticas, têm-se o estiramento de quartzo e o alinhamento descontínuo de biotitas e/ou horblenda configurando a foliação $S_{1}$ (Fig. 8B). O quartzo comumente exibe feiçóes de

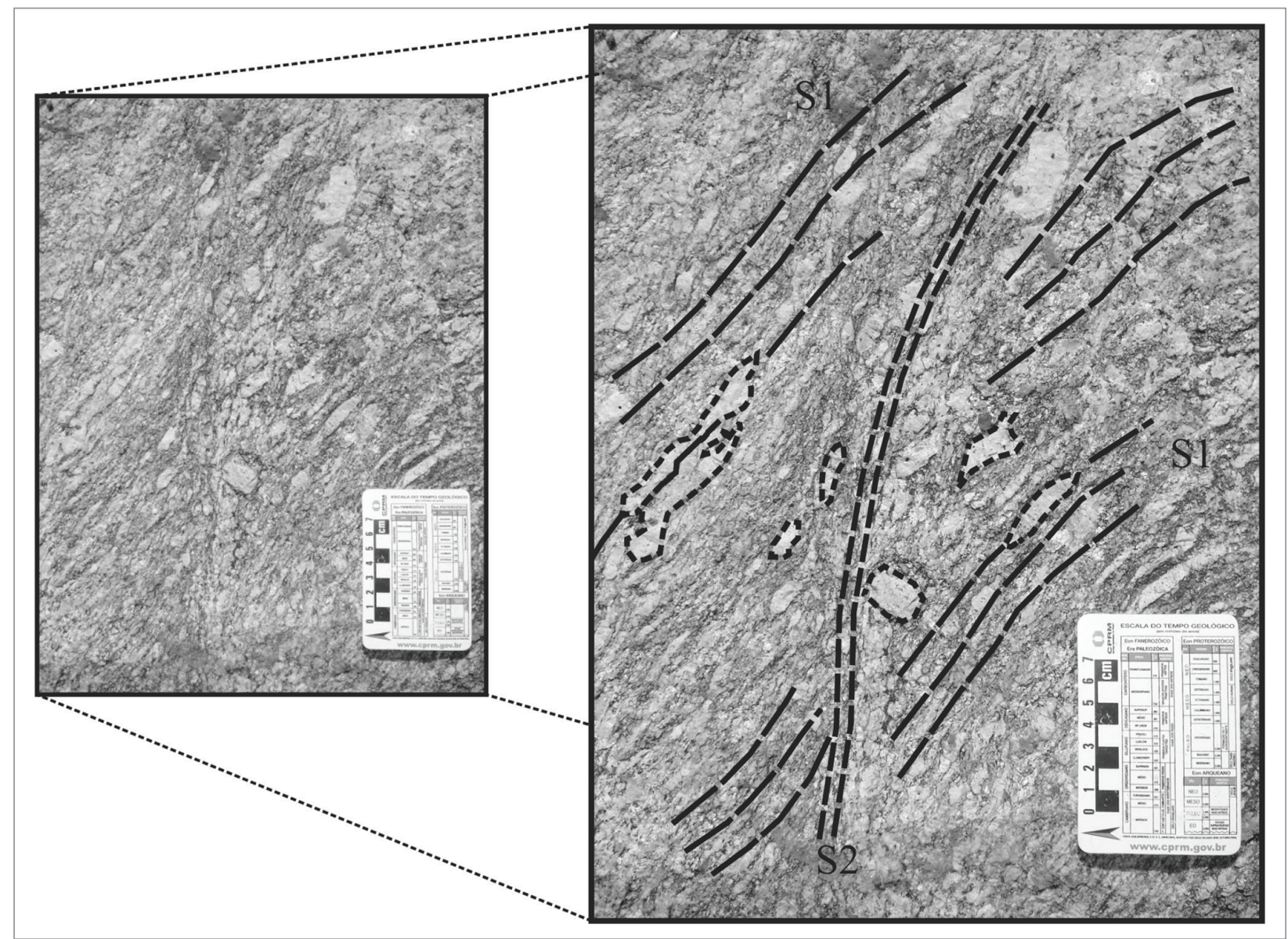

Figura 6. Aspectos de campo (em planta) ilustrando as foliações $\mathrm{S}_{1}$ e $\mathrm{S}_{2}$. Detalhe para o estiramento e rotação de grãos de feldspato alcalino. 
deformação intracristalina e plasticidade cristalina, como extinção ondulante, lamelas de deformação, ribbons e subgrãos, respectivamente. Quando os sienogranitos a granodioritos situam-se próximos de zonas de cisalhamento, observam-se: diminuição na quantidade e maior grau de arredondamento dos porfiroclastos de feldspatos, aumento na proporção de quartzo em ribbons e na matriz recristalizada, além de subgrãos de quartzo.

A fase $\mathrm{F}_{2}$ é marcada pela formação de dobras suaves da foliação $S_{1}$ que resulta em uma foliação não penetrativa $S_{2}$. A foliação $S_{2}$ é oblíqua a $S_{1}$ e coincide com a nucleação e desenvolvimento de discretas e estreitas zonas de cisalhamento dúcteis-rúpteis orientadas (Fig. 6) segundo a direção $\mathrm{N} 70$ - $80 \mathrm{~W}$ com mergulhos elevados, entre $70^{\circ}$ a $80^{\circ}$, para o quadrante NE.

\section{GEOQUÍMICA ELEMENTAL}

Doze amostras de rochas representativas do Batólito Guaporeí, considerando sua distribuição na área de estudo, bem como sua diversidade textural e mineralógica, foram selecionadas para análises químicas. Inicialmente, esses exemplares foram serrados e britados no laboratório de Laminação do Departamento de Recursos Minerais da UFMT e, em seguida, fez-se a separação de cerca de $50 \mathrm{~g}$ de cada amostra, sendo todas enviadas ao Acme Analytical Laboratories (Acmelab) Vancouver/Canadá para determinaçóes por meio dos métodos ICP-OES (Inductively Coupled Plasma Optical Emission) e ICP-MS (Inductively Coupled Plasma Mass Espectrometry) para elementos maiores, menores e traços, incluindo terras raras, sendo os resultados apresentados na Tab. 1.
As rochas do Batólito Guaporeí são de natureza ácida pouco expandida, com valores de $\mathrm{SiO}_{2}$ entre 63,81 e $73,96 \%$ (Tab. 1). Os diagramas de Harker (Fig. 9) mostram tendências de variação coerentes com correlaçóes lineares negativas entre sílica e $\mathrm{Al}_{2} \mathrm{O}_{3}, \mathrm{Fe}_{2} \mathrm{O}_{3 \mathrm{t}}, \mathrm{TiO}_{2}, \mathrm{MgO}, \mathrm{CaO}$ e $\mathrm{P}_{2} \mathrm{O}_{5}$, que refletem o empobrecimento em plagioclásio cálcico e em minerais máficos primários, como hornblenda, biotita, ilmenita-magnetita, titanita e apatita, durante a diferenciação. Dos álcalis, o $\mathrm{Na}_{2} \mathrm{O}$ não apresenta variação significativa com a sílica, enquanto os valores de $\mathrm{K}_{2} \mathrm{O}$ são sempre

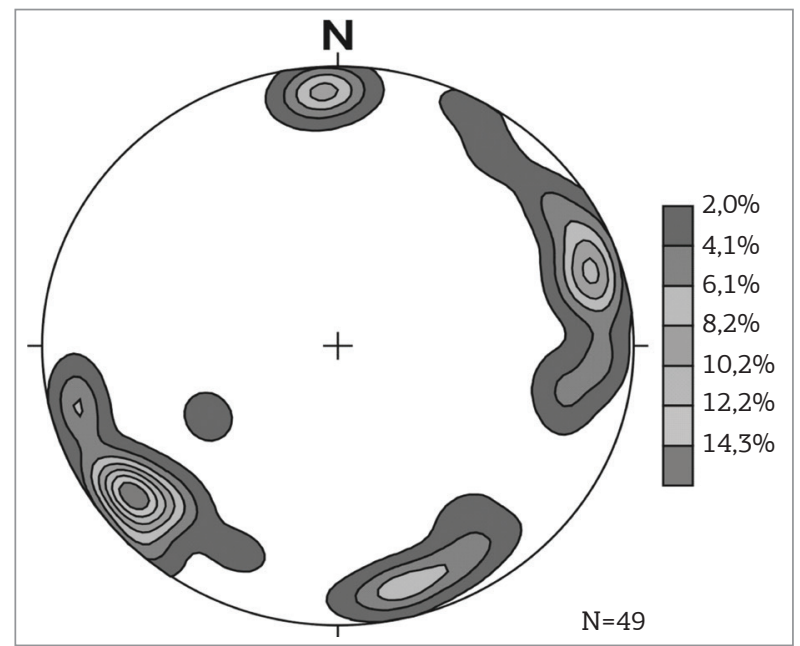

Figura 8. Fotomicrografia das rochas do Batólito Guaporeí ilustrando a foliação $S_{1}$ em: (A) alinhamento de palhetas de biotita e cristais anédricos de hornblenda, no monzogranito; (B) intercalação de ribbons de quartzo e palhetas de biotita definindo alinhamento nos quartzo-monzonitos.

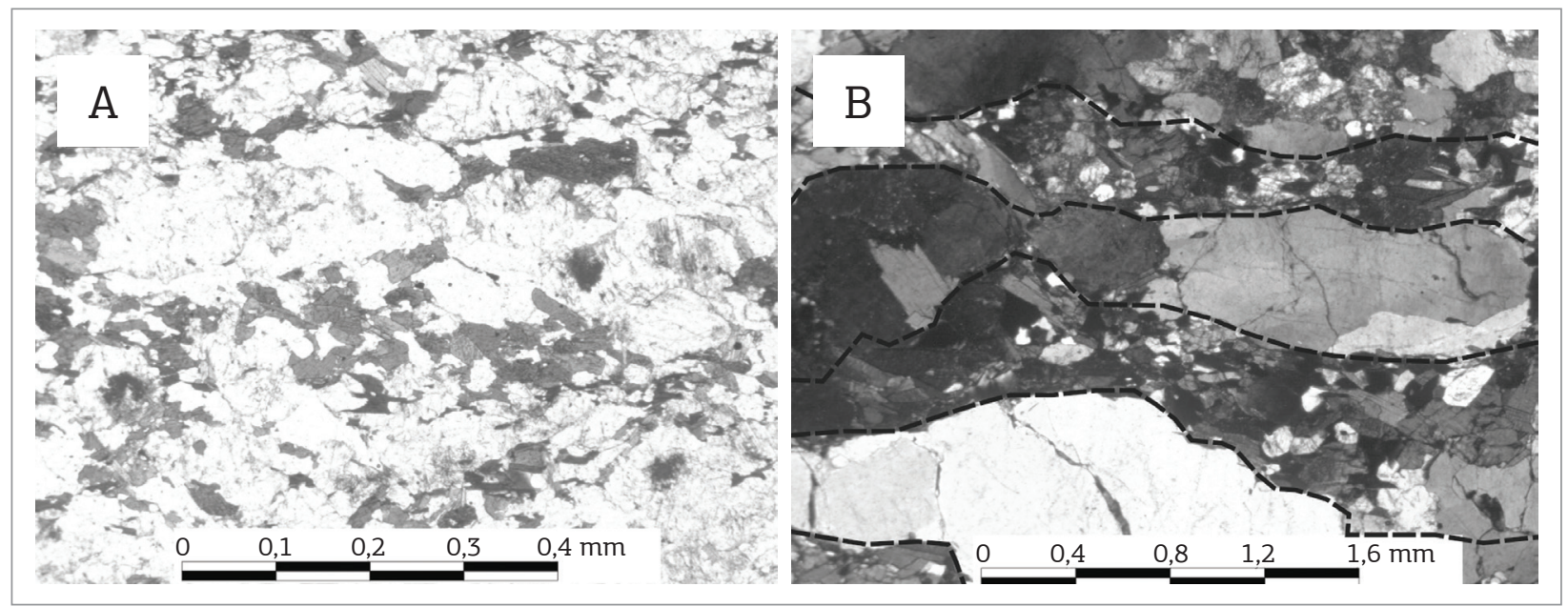

Figura 7. Estereograma para pólos da foliação $S_{1}$ do Granito Guaporeí. O máximo obtido, N40W/75NE, reflete a porção sul e central da intrusão, e os valores próximos a N75SE/75NW foram obtidos no setor norte do corpo. 
elevados com correlação positiva com esse índice, evidenciando um padrão de evolução que ilustra o enriquecimento em feldspatos alcalinos das rochas mais diferenciadas.

As rochas do Batólito Guaporeí foram classificadas como traquidacitos, dacitos e riolitos na representação gráfica Total de Álcalis versus sílica de Le Bas et al. (1986; Fig. 10A), como granitos na Q - P proposto por Debon \& Le Fort (1988; Fig 10B), e como granodioritos e monzo a sienogranitos no diagrama $R_{1} x R_{2}$ (La Roche 1980; Fig. 10C), que considera a maioria dos elementos maiores. $\mathrm{O}$ gráfico $\mathrm{K}_{2} \mathrm{O}+\mathrm{Na}_{2} \mathrm{O}$ versus $\mathrm{SiO}_{2}$ com limite dos domínios subalcalino e alcalino, proposto por Irvine \& Baragar (1971), e o AFM, do mesmo autor, ilustrados respectivamente nas figuras 10A e 10D, indicam que o magmatismo que originou as rochas estudadas caracteriza-se como subalcalino do tipo cálcio-alcalino. A natureza de alto $\mathrm{K}$ a shoshonítica desse magma é sugerida pelo diagrama $\mathrm{K}_{2} \mathrm{O}$ versus $\mathrm{SiO}_{2}$ (Peccerillo \& Taylor 1976; Fig. 10E) e sua afinidade entre metaluminosa e peraluminosa é ilustrada no gráfico A/NK versus A/CNK (Maniar \& Piccoli 1989; Fig. 10F).

Os teores dos Elementos Terras Raras (ETR) das rochas do Batólito Guaporeí, normalizados pelos valores condríticos de Nakamura (1977), mostram, para a maioria das amostras, pequenas variaçóes e distribuiçóes similares (Fig. 11A). Os padrôes das rochas dominantes evidenciam distribuição de ETR marcada pelo enriquecimento de ETRL sobre pesados, porém com razóes $(\mathrm{La} / \mathrm{Yb})_{\mathrm{N}}$ muito variáveis (6,59 a 89,52; Tab. 1) e pronunciadas anomalias negativas de $\mathrm{Eu}\left(\mathrm{Eu} / \mathrm{Eu}^{*}\right.$ entre 0,21 e 0,62; Fig. 11A).

No diagrama multielementos (Fig. 11B), que apresenta diversos elementos traço além de $\mathrm{K}_{2} \mathrm{O}$ normalizados contra os valores de granitos de Cordilheira Meso-Oceânica de Pearce et al. (1984), observam-se padróes de enriquecimento dos elementos litófilos de íons grandes (LILE) em relação aos elementos de alta carga (HFSE). No grupo dos LILE, destaca-se anomalia positiva de Rb em relação a $\mathrm{K}_{2} \mathrm{O}$ e Ba pelo fracionamento de feldspatos alcalinos e plagioclásio; e anomalias positivas de Th. No grupo dos HFSE, notam-se baixos valores de $\mathrm{Ta}$ e $\mathrm{Nb}$, anomalia positiva de Ce e $\mathrm{Sm}$ em relação aos elementos adjacentes. Os valores normalizados de $\mathrm{Y}$ e $\mathrm{Yb}$, geralmente inferiores a 1 , assemelham-se àqueles encontrados em rochas cálcio-alcalinas de alto $\mathrm{K}$.

O diagrama $\mathrm{Nb}$ versus $\mathrm{Y}$ (Fig. 11C; campos de Pearce et al. 1984) indica que a maioria das rochas do Batólito Guaporeí possui composição compatível com a de granitos fanerozoicos gerados em ambiente de arco magmático em período sincolisional. A similaridade geoquímica com as rochas formadas em ambiente de arco é corroborada pelo diagrama $\mathrm{Hf}-\mathrm{Rb}-\mathrm{Ta}$ (Fig. 11D; campos de Harris et al. 1986).

\section{GEOCRONOLOGIA E GEOQUÍMICA ISOTÓPICA}

As amostras foram tratadas no Laboratório de Preparação de Amostras do Departamento de Recursos Minerais (DRM) da UFMT. As dataçôes $\mathrm{Pb}-\mathrm{Pb}$ em zircão (evaporação) foram realizadas no Laboratório de Geologia Isotópica (Pará-Iso), da Universidade Federal do Pará, enquanto as análises $\mathrm{Sm}-\mathrm{Nd}$ em rocha total foram realizadas no Laboratório de Geocronologia do Instituto de Geociências, da Universidade de Brasília. Em ambos os casos, as análises isotópicas foram feitas em um espectrômetro de massa Finnigan MAT 262. As amostras datadas correspondem aos monzogranitos JR76, JR83 (Pb-Pb em zircão - evaporação) e GJ15 (Sm-Nd em rocha total).

\section{Procedimentos analíticos}

Os concentrados de zircão foram obtidos por meio das técnicas convencionais de moagem e separaçáo mineral (peneiramento, líquidos densos e separador magnético). Os cristais de zircão foram escolhidos manualmente da granulação 0,170 mm da fração menos magnética e dispostos em um filamento de rênio sob a forma de canoa. Fez-se o uso de mais de um grão de zircão por canoa em razão das baixas concentraçôes de $\mathrm{Pb}$ radiogênico dos zircôes analisados. As análises $\mathrm{Pb} / \mathrm{Pb}$ em multigrãos de zircão foram realizadas por ionização termal, mediante o sistema de detector de contagem de íons para os isótopos ${ }^{204} \mathrm{~Pb},{ }^{206} \mathrm{~Pb}$, ${ }^{207} \mathrm{~Pb} \mathrm{e}{ }^{208} \mathrm{~Pb}$, que permite medidas precisas para baixas razóes de ${ }^{206} \mathrm{~Pb} /{ }^{204} \mathrm{~Pb}$. As calibraçôes foram feitas usando o padrão NBS 983. A média das idades foi calculada com precisão de $2 \sigma$ ( $\pm 95 \%$ de precisão), segundo metodologia descrita em Gaudette et al. (1998). Cada canoa com multigrãos de zircão foi analisada em diferentes temperaturas $\left(1.450^{\circ} \mathrm{C}, 1.500^{\circ} \mathrm{C}\right.$ e $\left.1.550^{\circ} \mathrm{C}\right)$. As idades foram calculadas usando as constantes de decaimento e abundâncias isotópicas listadas por Steiger \& Jäger (1977).

A técnica analítica Samário-Neodímio utiliza amostras previamente pulverizadas, levadas à abertura por via úmida com $\mathrm{HF}$ e $\mathrm{HNO}_{3}$ em forno de micro-ondas. Em seguida, é realizada a separação química em duas etapas, utilizando-se colunas de cromatografia de troca iônica. Na primeira coluna, é feita a separação dos elementos terras raras dos demais elementos maiores. Na segunda coluna, faz-se a separação de $\mathrm{Sm}$ e Nd dos elementos terras raras. A análise é realizada por espectrometria de massa, sendo que o depósito de $\mathrm{Nd}$ é feito em filamento de Ta e o de Sm, em filamento de Re. Na análise química, é empregado um arranjo de filamento duplo, constituído de um filamento de evaporação, no qual é feito o depósito de Sm ou Nd, e um filamento de ionização. 
Tabela 1. Composição química de elementos maiores, menores e traços (óxidos percentual em peso e elementos traço em ppm) de rochas do Batólito Guaporeí

\begin{tabular}{|c|c|c|c|c|c|c|c|c|c|c|c|c|}
\hline Amostras & JR116 & FL12A & FL15 & AT44 & GJ10 & FL45 & JR05 & SL76 & PN13 & GJ15 & JR03 & GJ05 \\
\hline $\begin{array}{l}\text { Classificação/ } \\
\text { elementos }\end{array}$ & Monzo & Monzo & Monzo & $\begin{array}{l}\text { Qz- } \\
\text { Monz }\end{array}$ & $\begin{array}{l}\text { Qz- } \\
\text { Monz }\end{array}$ & Monzo & Sieno & Monzo & Monzo & Monzo & Sieno & Sieno \\
\hline $\mathrm{SiO}_{2}$ & 63,81 & 65,05 & 66,48 & 66,60 & 67,01 & 67,34 & 68,11 & 68,42 & 69,62 & 71,22 & 71,84 & 73,96 \\
\hline $\mathrm{TiO}_{2}$ & 0,88 & 1,05 & 0,65 & 0,46 & 0,34 & 0,52 & 0,58 & 0,56 & 0,34 & 0,27 & 0,23 & 0,25 \\
\hline $\mathrm{Al}_{2} \mathrm{O}_{3}$ & 15,21 & 13,67 & 14,85 & 15,84 & 16,15 & 14,68 & 14,72 & 13,82 & 14,59 & 14,34 & 13,82 & 12,05 \\
\hline $\mathrm{Fe}_{2} \mathrm{O}_{3}$ & 5,83 & 6,50 & 5,21 & 3,92 & 2,72 & 4,71 & 3,77 & 3,85 & 3,11 & 2,21 & 2,05 & 3,45 \\
\hline $\mathrm{MgO}$ & 1,60 & 1,27 & 1,10 & 1,02 & 0,76 & 0,99 & 0,82 & 0,70 & 0,78 & 0,59 & 0,35 & 0,11 \\
\hline $\mathrm{MnO}$ & 0,08 & 0,08 & 0,04 & 0,03 & 0,03 & 0,03 & 0,05 & 0,05 & 0,03 & 0,02 & 0,03 & 0,05 \\
\hline $\mathrm{CaO}$ & 3,25 & 3,05 & 1,99 & 2,39 & 2,02 & 1,95 & 2,18 & 1,57 & 2,16 & 1,7 & 1,07 & 0,41 \\
\hline $\mathrm{Na}_{2} \mathrm{O}$ & 2,98 & 2,68 & 2,81 & 3,19 & 3,47 & 2,70 & 3,01 & 2,85 & 3,21 & 3,29 & 2,81 & 2,97 \\
\hline $\mathrm{K}_{2} \mathrm{O}$ & 4,55 & 4,86 & 5,67 & 5,09 & 6,29 & 5,82 & 5,77 & 5,61 & 4,76 & 5,29 & 6,59 & 5,95 \\
\hline $\mathrm{P}_{2} \mathrm{O}_{5}$ & 0,29 & 0,45 & 0,17 & 0,28 & 0,14 & 0,13 & 0,18 & 0,17 & 0,13 & 0,09 & 0,10 & 0,04 \\
\hline $\mathrm{Cr}_{2} \mathrm{O}_{3}$ & 0,005 & 0,003 & 0,008 & 0,002 & 0,003 & 0,006 & $<0,001$ & 0,002 & 0,002 & 0,002 & $<0,001$ & 0,004 \\
\hline LOI & 1,10 & 0,70 & 0,60 & 0,90 & 0,80 & 0,80 & 0,60 & 2,00 & 0,90 & 0,70 & 0,90 & 0,40 \\
\hline Total & 99,55 & 99,53 & 99,61 & 99,68 & 99,74 & 99,63 & 99,79 & 99,60 & 99,66 & 99,73 & 99,79 & 99,64 \\
\hline Sc & 13,00 & 14,00 & 7,00 & 6,00 & 3,00 & 7,00 & 8,00 & 6,00 & 2,00 & 3,00 & 3,00 & 2,00 \\
\hline $\mathrm{Ba}$ & 1387 & 1644 & 1222 & 1276 & 1751,1 & 1088 & 1229,6 & 1277 & 1401 & 1091,3 & 1413,7 & 332 \\
\hline Co & 10,70 & 29,80 & 22,00 & 7,00 & 58,90 & 22,20 & 83,80 & 5,20 & 5,40 & 75,40 & 111,20 & 162,50 \\
\hline Cs & 0,60 & 1,90 & 1,50 & 2,10 & 1,30 & 1,40 & 0,40 & 4,50 & 1,30 & 1,00 & 0,90 & 0,50 \\
\hline $\mathrm{Ga}$ & 20,30 & 21,10 & 19,90 & 22,10 & 21,80 & 20,10 & 22,20 & 19,00 & 18,00 & 19,10 & 17,80 & 26,50 \\
\hline $\mathrm{Hf}$ & 18,70 & 16,30 & 12,60 & 8,00 & 7,70 & 10,90 & 14,00 & 18,00 & 9,10 & 6,40 & 8,50 & 23,00 \\
\hline $\mathrm{Nb}$ & 22,50 & 26,40 & 22,70 & 11,50 & 11,30 & 15,70 & 14,70 & 24,40 & 8,80 & 5,20 & 6,80 & 15,80 \\
\hline $\mathrm{Rb}$ & 155,50 & 180,90 & 246,20 & 217,30 & 210,00 & 250,30 & 172,10 & 244,00 & 156,40 & 183,20 & 246,50 & 135,00 \\
\hline Sn & 5,00 & 6,00 & 4,00 & 2,00 & 3,00 & 4,00 & 3,00 & 5,00 & 2,00 & 1,00 & 2,00 & 3,00 \\
\hline $\mathrm{Sr}$ & 338,10 & 353,20 & 258,90 & 312,30 & 645,40 & 254,30 & 307,30 & 279,50 & 538,90 & 315,70 & 376,40 & 93,40 \\
\hline $\mathrm{Ta}$ & 1,20 & 1,80 & 0,40 & 0,50 & 1,20 & 0,40 & 0,50 & 1,40 & 0,70 & 0,30 & 0,90 & 0,80 \\
\hline Th & 14,90 & 20,20 & 114,90 & 35,40 & 50,80 & 102,60 & 26,00 & 33,90 & 32,90 & 29,90 & 90,10 & 24,50 \\
\hline $\mathrm{U}$ & 1,50 & 3,40 & 2,00 & 3,60 & 2,90 & 1,80 & 0,80 & 2,80 & 1,80 & 1,90 & 3,60 & 2,10 \\
\hline $\mathrm{V}$ & 71,00 & 90,00 & 56,00 & 44,00 & 43,00 & 51,00 & 50,00 & 35,00 & 33,00 & 28,00 & 26,00 & $<8,00$ \\
\hline W & $<0,50$ & 198,30 & 113,20 & $<0,50$ & 321,30 & 114,00 & 432,30 & $<0,50$ & $<0,50$ & 405,40 & 598,30 & 941,60 \\
\hline $\mathrm{Zr}$ & 667,20 & 599,70 & 406,60 & 270,70 & 285,50 & 355,20 & 488,60 & 620,70 & 280,20 & 225,40 & 292,90 & 721,20 \\
\hline $\mathrm{Y}$ & 114,4 & 110,8 & 17,7 & 41,7 & 26,3 & 18,7 & 39,3 & 114,0 & 18,8 & 11,5 & 22,3 & 147,4 \\
\hline Mo & 0,90 & 3,80 & 7,80 & 0,30 & 0,10 & 6,40 & 0,80 & 1,10 & 0,60 & 0,10 & 0,90 & 5,80 \\
\hline $\mathrm{Cu}$ & 23,30 & 13,60 & 37,80 & 18,60 & 7,00 & 25,50 & 6,80 & 11,10 & 7,70 & 4,70 & 10,70 & 17,70 \\
\hline $\mathrm{Pb}$ & 6,40 & 6,20 & 15,60 & 6,60 & 10,30 & 13,10 & 5,80 & 10,30 & 9,20 & 9,00 & 16,50 & 41,90 \\
\hline $\mathrm{Zn}$ & 101,00 & 100,00 & 86,00 & 63,00 & 37,00 & 73,00 & 69,00 & 77,00 & 43,00 & 45,00 & 33,00 & 76,00 \\
\hline $\mathrm{Ni}$ & 15,50 & 16,50 & 34,10 & 9,30 & 6,90 & 29,10 & 3,80 & 3,60 & 8,90 & 4,60 & 4,50 & 22,90 \\
\hline As & $<0,50$ & 0,70 & $<0,50$ & $<0,50$ & $<0,50$ & $<0,50$ & $<0,50$ & 0,50 & 0,60 & $<0,50$ & $<0,50$ & $<0,50$ \\
\hline $\mathrm{Au}$ & $<0,50$ & 1,60 & 1,60 & 0,70 & $<0,50$ & 1,40 & 1,50 & $<0,50$ & $<0,50$ & $<0,50$ & $<0,50$ & $<0,50$ \\
\hline $\mathrm{La}$ & 103,10 & 119,20 & 131,60 & 80,50 & 102,30 & 122,30 & 125,30 & 107,60 & 94,80 & 38,60 & 143,50 & 87,50 \\
\hline $\mathrm{Ce}$ & 269,90 & 262,40 & 279,20 & 167,10 & 210,30 & 265,40 & 275,50 & 263,50 & 197,30 & 79,50 & 297,30 & 232,90 \\
\hline $\operatorname{Pr}$ & 32,37 & 38,21 & 33,86 & 17,33 & 21,76 & 32,91 & 32,53 & 30,23 & 19,13 & 8,16 & 31,95 & 23,67 \\
\hline $\mathrm{Nd}$ & 127,10 & 158,20 & 123,50 & 61,60 & 73,50 & 120,40 & 117,50 & 117,40 & 63,70 & 27,30 & 104,50 & 88,10 \\
\hline Sm & 23,70 & 29,31 & 17,60 & 8,31 & 9,16 & 17,49 & 17,52 & 22,72 & 8,01 & 3,62 & 13,37 & 16,61 \\
\hline $\mathrm{Eu}$ & 2,34 & 4,13 & 1,61 & 1,29 & 1,42 & 1,54 & 1,84 & 1,97 & 1,21 & 0,92 & 1,33 & 1,05 \\
\hline $\mathrm{Gd}$ & 20,40 & 25,79 & 11,93 & 5,38 & 5,45 & 11,65 & 11,90 & 19,66 & 4,74 & 2,00 & 6,90 & 14,52 \\
\hline $\mathrm{Tb}$ & 3,25 & 3,91 & 1,30 & 0,98 & 0,89 & 1,28 & 1,74 & 3,33 & 0,70 & 0,33 & 0,96 & 2,24 \\
\hline Dy & 18,21 & 20,68 & 4,78 & 6,41 & 4,27 & 4,96 & 7,41 & 19,32 & 3,48 & 1,84 & 4,16 & 11,51 \\
\hline Ho & 3,71 & 4,14 & 0,65 & 1,30 & 0,71 & 0,70 & 1,23 & 3,96 & 0,65 & 0,29 & 0,61 & 2,25 \\
\hline $\mathrm{Er}$ & 10,77 & 11,09 & 1,39 & 3,57 & 1,97 & 1,49 & 3,03 & 11,35 & 1,88 & 0,88 & 1,71 & 5,93 \\
\hline $\mathrm{Tm}$ & 1,53 & 1,64 & 0,16 & 0,46 & 0,35 & 0,19 & 0,48 & 1,78 & 0,29 & 0,14 & 0,31 & 0,88 \\
\hline $\mathrm{Yb}$ & 8,98 & 9,59 & 0,98 & 2,54 & 2,13 & 1,04 & 2,58 & 10,88 & 1,69 & 0,83 & 1,75 & 5,16 \\
\hline $\mathrm{Lu}$ & 1,25 & 1,33 & 0,16 & 0,38 & 0,3 & 0,16 & 0,38 & 1,57 & 0,25 & 0,12 & 0,24 & 0,81 \\
\hline $\mathrm{Eu} / \mathrm{Eu}^{*}$ & 0,33 & 0,46 & 0,34 & 0,59 & 0,62 & 0,33 & 0,39 & 0,29 & 0,60 & 1,05 & 0,43 & 0,21 \\
\hline $\mathrm{La} / \mathrm{Yb}^{*}$ & 7,65 & 8,29 & 89,52 & 21,13 & 32,02 & 78,40 & 32,38 & 6,59 & 37,40 & 31 & 54,67 & 11,30 \\
\hline
\end{tabular}




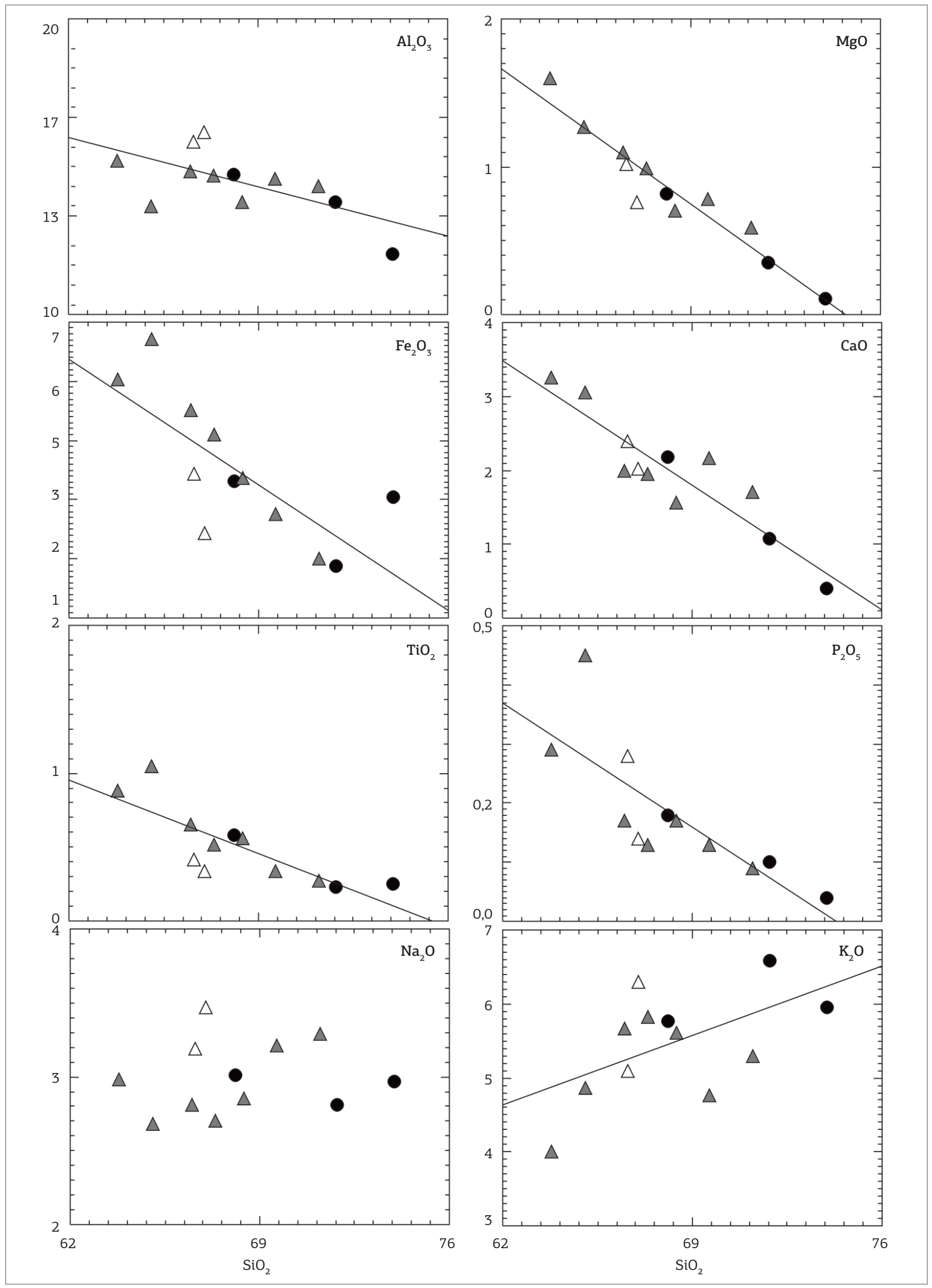

Figura 9. Diagramas de variações de Harker para elementos maiores (expressos em óxidos) das rochas do Batólito Guaporeí. Símbolos: sienogranito; $\Delta$ monzogranito; $\triangle$ quartzo-monzonito. 

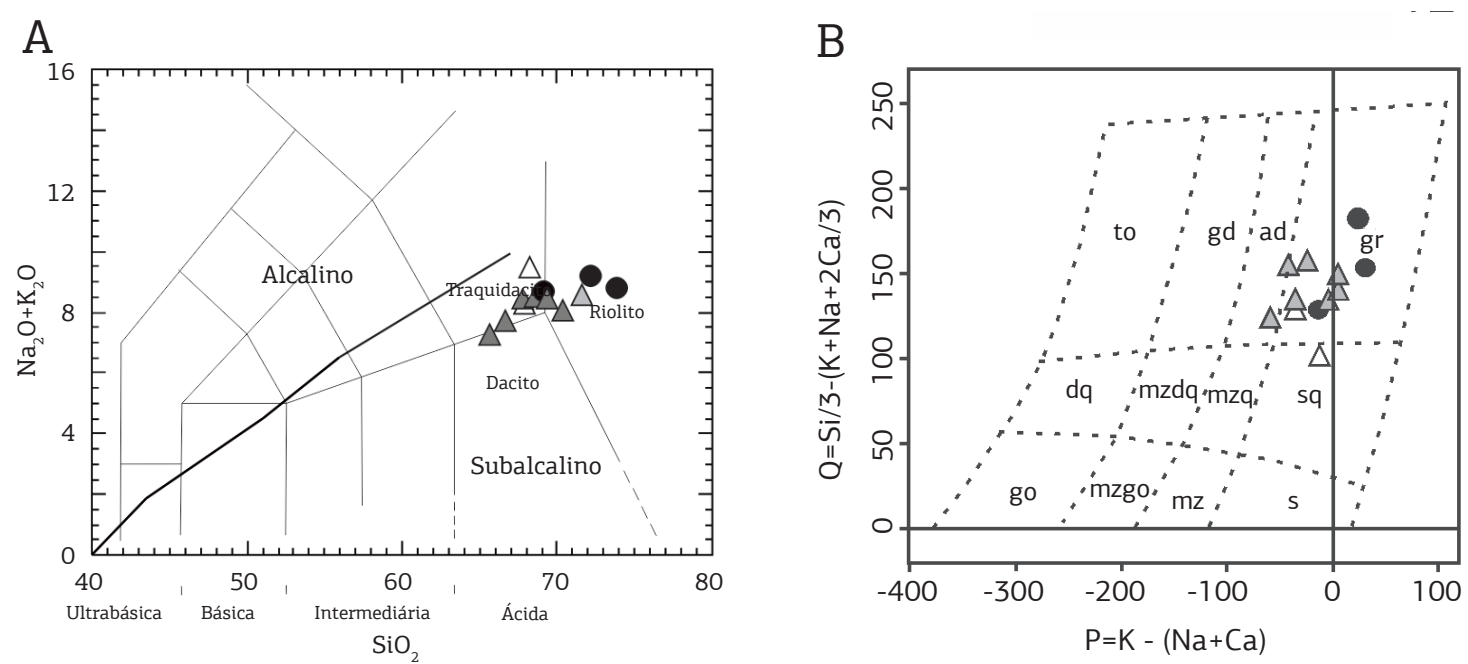

C
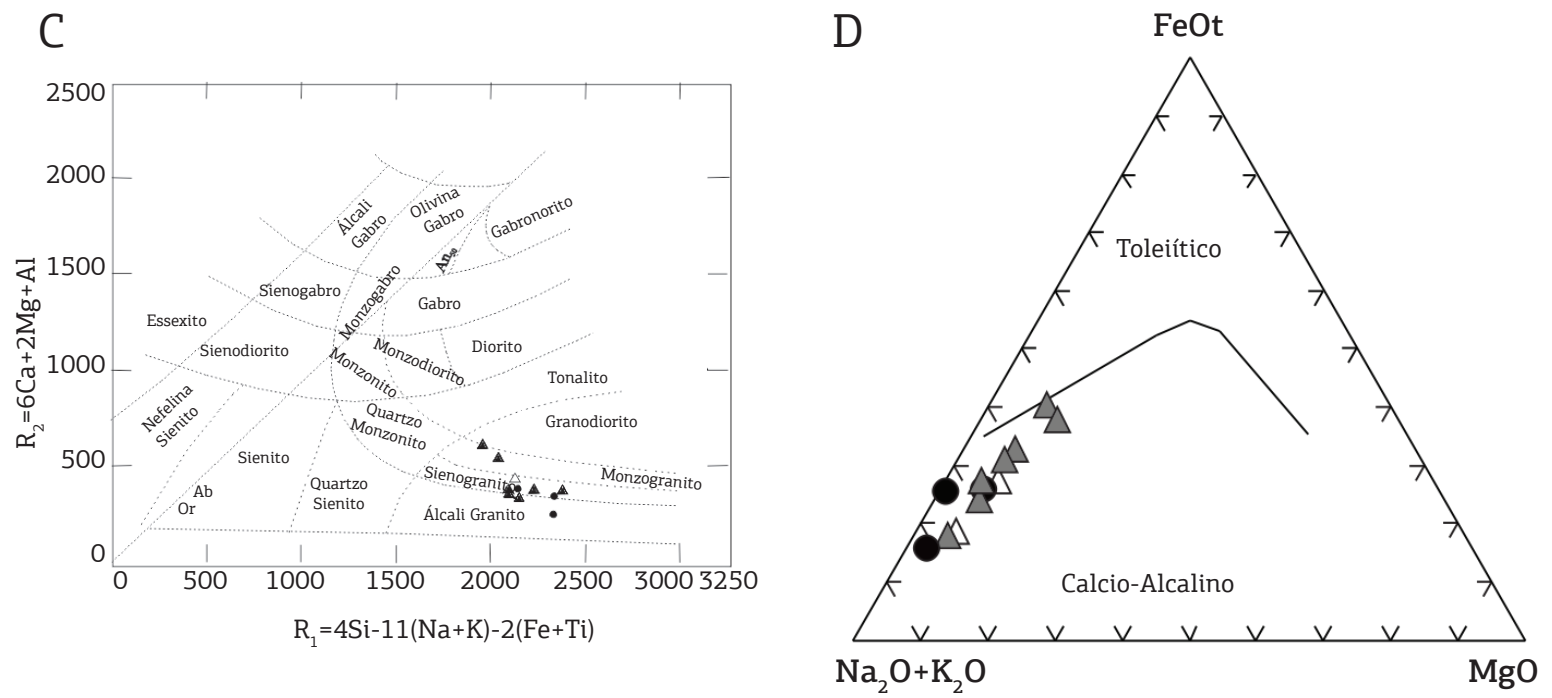

$\mathrm{F}$
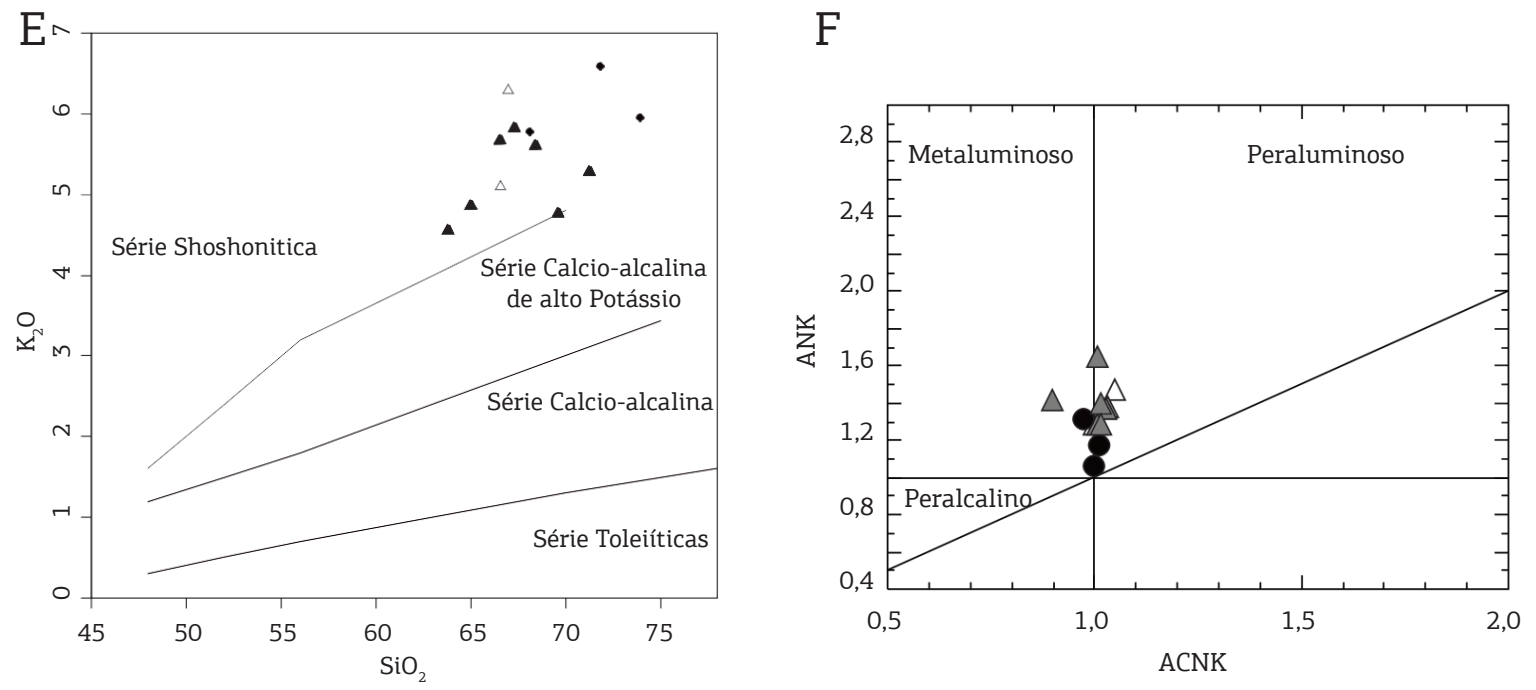

Figura 10. Diagramas classificatórios para as rochas do Batólito Guaporeí: (A) total de álcalis versus sílica (Le Bas et al. 1986) com limite entre domínio alcalino/subalcalino de Irvine \& Baragar (1971); (B) Q-P (Debon \& Le Fort 1988); (C) $\mathrm{R}_{1} \times \mathrm{R}_{2}$ (La Roche 1980): (D) AFM (Irvine \& Baragar 1971); (E) $\mathrm{K}_{2} \mathrm{O}$ versus $\mathrm{SiO}_{2}$ (Peccerillo \& Taylor 1976); (F) A/NK versus A/CNK (Maniar \& Piccoli 1989). Símbolos como na Fig. 9. 

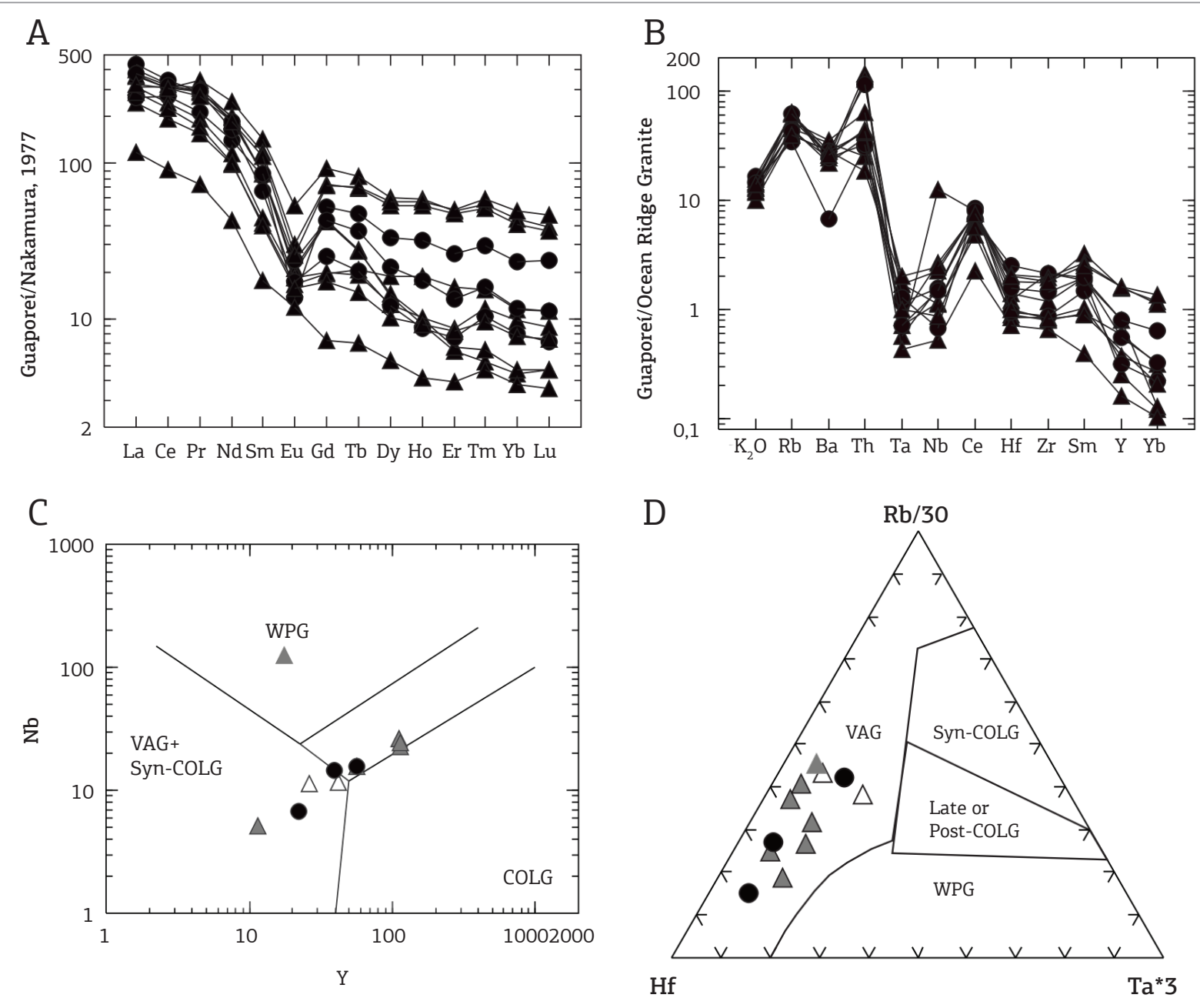

Figura 11. Padrões de distribuição das rochas do Batólito Guaporeí nos diagramas: em (A) ETR, normalizados pelos valores condríticos (Nakamura 1977); (B) elementos traço e $\mathrm{K}_{2} \mathrm{O}$ das rochas do Batólito Guaporeí, normalizados pelos valores dos granitos de Cordilheira Meso-Oceânica (Pearce et al. 1984). Diagramas de classificação tectônica para as rochas do Batólito Guaporeí: (C) Nb versus Y (Pearce et al. 1984); (D) Hf-Rb/30-Ta*3 (Harris et al. 1986). Símbolos como na Fig. 9.

As medidas dos conteúdos e razôes isotópicas de Nd resultaram de ionização termal, com sistemas de coletores simples e múltiplos. As razóes ${ }^{143} \mathrm{Nd} /{ }^{144} \mathrm{Nd}$ foram normalizadas pelos valores $\mathrm{de}{ }^{146} \mathrm{Nd} /{ }^{144} \mathrm{Nd}=0,7219$ e, posteriormente, ajustadas pelos padróes NBS987 e La Jolla, respectivamente. Os cálculos das idades-modelo foram feitos com base na curva de evoluçâo do manto empobrecido de DePaolo (1981).

\section{Resultados analíticos $\mathrm{Pb}-\mathrm{Pb}$ em zircão (evaporação)}

Para datação geocronológica pelo método $\mathrm{Pb}-\mathrm{Pb}$ em zircão do Batólito Guaporeí, foram selecionadas duas amostras (JR76 e JR83). Apenas os resultados da primeira delas foram satisfatórios e serão considerados neste trabalho. Os dados relativos à amostra JR83, embora mostrem baixas razóes de $\mathrm{Pb}$ comum, foram descartados por apresentarem um número restrito da razão utilizada na interpretação (inferior a quatro). A amostra JR76 corresponde a um monzogranito intensamente foliado aflorante na parte sudeste do Batólito, próximo à zona de cisalhamento, e os dados analíticos obtidos estão apresentados na Tab. 2. Apresenta textura inequigranular grossa a porfirítica, com fenocristais de feldspato alcalino estirados segundo a foliação regional principal, imersos em uma matriz quartzo-feldspática rica em biotita. Os cristais de zircão desta amostra variam de marrom a marrom-amarelado, são prismáticos a anédricos arredondados, curtos, com núcleos bem turvos, exibindo moderado faturamento. Raros exemplares apresentam geminação e zonação. São comuns feiçóes de alteração metamítica, como opacidade, fraturamento e coloração leitosa. Dessa forma, para a análise, foram escolhidos os cristais menos afetados por esse processo (Fig. 12). 
Cento e trinta cristais selecionados foram dispostos em grupo de quatro a cinco grãos, totalizando 26 filamentos de rênio, das quais apenas 11 foram analisados. Desses, seis foram eliminados por causa das baixas emissóes de $\mathrm{Pb}$ para as análises. Os cinco filamentos restantes apresentaram bons resultados analíticos, obtidos durante a segunda etapa de aquecimento $\left(1.500{ }^{\circ} \mathrm{C}\right)$. A fim de reduzir o desvio sobre a idade, optou-se pelo uso dos resultados de apenas quatro filamentos $(10,11,13$ e 17), os quais forneceram as 118 razóes isotópicas (Tab. 2) utilizadas no cálculo da idade média de $1.314 \pm 3 \mathrm{Ma}$ (MSWD = 0,12) considerada como a idade de cristalização para as rochas do Batólito Guaporeí (Fig. 13).

\section{Resultados analíticos de Sm-Nd em rocha total}

A amostra selecionada para estudo isotópico de $\mathrm{Sm}-\mathrm{Nd}$ corresponde a um monzogranito (GJ15), localizado na parte

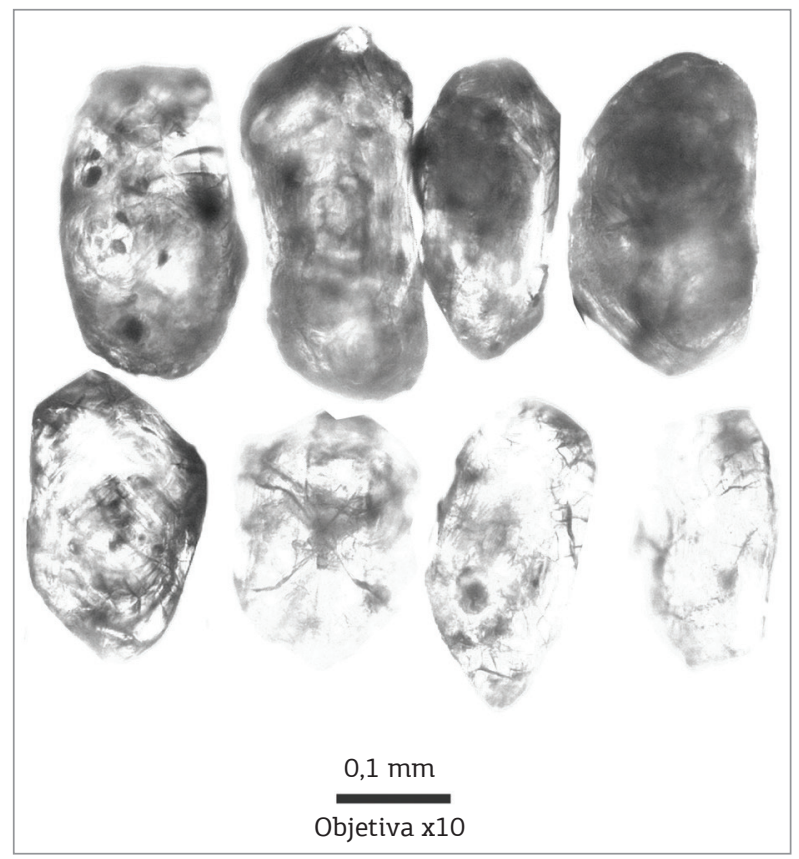

Figura 12. Fotomicrografia de cristais de zircão da amostra JR76 selecionados para datação. sudoeste do Batólito. Consiste por uma rocha de textura inequigranular grossa a porfirítica, com foliação incipiente e fenocristais de feldspato alcalino de até $3 \mathrm{~cm}$. Os resultados analíticos obtidos indicam razóes ${ }^{147} \mathrm{Sm} /{ }^{144} \mathrm{Nd}$ de 0,0841 , idade-modelo $\mathrm{T}_{\mathrm{DM}}$ de 1,76 Ga (Tab. 3), considerada como indicativa do período em que houve extração do magma do manto superior, enquanto o valor negativo de $\varepsilon_{\mathrm{Nd}(t=1,3)}(-14)$ é condizente com os valores apresentados por granitos de origem crustal, sugerindo processos de fusão parcial da crosta continental na geração do magma.

\section{CONCLUSÕES}

O SW do Cráton Amazônico é constituído por diversos terrenos ou fragmentos crustais que foram sendo aglutinados durante o Mesoproterozoico, ao longo de vários episódios orogênicos. O Batólito Guaporeí insere-se na Província Rondoniana-San Ignácio (1,56 a 1,3 Ga) conforme a definiçáo de Bettencourt et al. (2010) e faz parte do principal evento magmático registrado no Terreno Paraguá (Ruiz 2009) durante a evolução da orogenia San Ignácio (1,37 a 1,3 Ga).

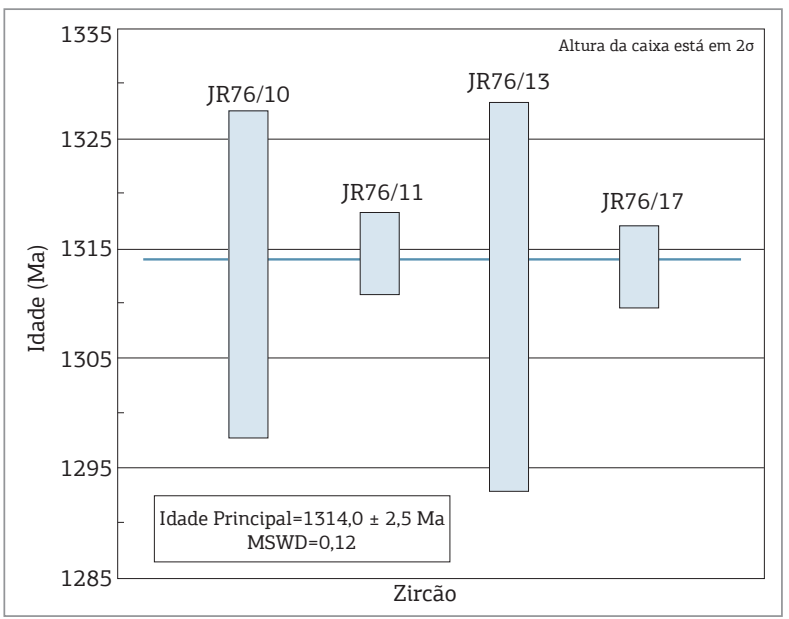

Figura 13. Diagrama idades versus cristais de zircão para a amostra JR76 do Batólito Guaporeí.

Tabela 2. Dados isotópicos de Pb de multigrãos de zircão da amostra JR76 do Batólito Guaporeí

\begin{tabular}{|c|c|c|c|c|c|c|c|c|c|c|}
\hline Amostra & $\mathrm{T}^{\circ} \mathrm{C}$ & Razões & ${ }^{204} \mathrm{~Pb} /{ }^{206} \mathrm{~Pb}$ & $2 \sigma$ & $\left({ }^{208} \mathrm{~Pb} /{ }^{206} \mathrm{~Pb}\right) \mathrm{c}$ & $2 \sigma$ & $\left({ }^{207} \mathrm{~Pb} /{ }^{206} \mathrm{~Pb}\right) \mathrm{c}$ & $2 \sigma$ & Idade & $2 \sigma$ \\
\hline JR76/10 & 1.500 & $8 / 8$ & 0,000229 & 0,000002 & 0,12218 & 0,00789 & 0,08588 & 0,00165 & $1.312,8$ & 14,9 \\
\hline JR76/11 & 1.500 & $54 / 108$ & 0,000129 & 0,000009 & 0,08947 & 0,00215 & 0,08495 & 0,00016 & $1.314,7$ & 3,7 \\
\hline JR76/13 & 1.500 & $38 / 62$ & 0,000302 & 0,00002 & 0,08287 & 0,00084 & 0,08478 & 0,00078 & $1.310,8$ & 17,8 \\
\hline \multirow[t]{2}{*}{ JR76/17 } & 1.500 & $18 / 38$ & 0,000588 & 0,000005 & 0,07645 & 0,00209 & 0,08490 & 0,00017 & $1.313,5$ & 3,8 \\
\hline & & $118 / 216$ & & & & & Idade Média: & 1.314 & & 2,5 \\
\hline
\end{tabular}

Tabela 3. Dados analíticos de Sm-Nd do Batólito Guaporeí

\begin{tabular}{l|c|c|c|c|c|c|c}
\hline Amostra & $\mathbf{S m}(\mathbf{p p m})$ & $\mathbf{N d}(\mathbf{p p m})$ & ${ }^{147} \mathbf{S m} /{ }^{144} \mathbf{N d}$ & ${ }^{143} \mathbf{N d} /{ }^{144} \mathbf{N d}( \pm \mathbf{2 S E})$ & $\varepsilon_{\mathbf{N d}(0)}$ & $\mathbf{T}_{\mathrm{DM}}(\mathbf{G a})$ & $\varepsilon_{\mathbf{N d}(\mathrm{t}=1,3)}$ \\
\hline GJ15 & 4,385 & 31,504 & 0,0841 & $0,511540+/-5$ & $-21,42$ & 1,76 & -14 \\
\hline
\end{tabular}


O Batólito Guaporeí consiste de monzogranitos, com sienogranitos e quartzo-monzonitos, subordinados, que têm biotita \pm hornblenda como máficos primários; anisotrópicos, com foliação bem marcada, afetados por duas fases de deformação $\left(\mathrm{F}_{1}\right.$ e $\left.\mathrm{F}_{2}\right)$ relacionadas à orogenia San Ignácio. Geoquimicamente, essas rochas constituem uma sequência ácida formada por um magmatismo subalcalino, do tipo cálcio-alcalino de alto potássio a shoshonítico, metaluminoso a levemente peraluminoso, evoluído por meio de mecanismos de cristalização fracionada associados à contaminação crustal. Os dados geocronológicos $\mathrm{Pb}-\mathrm{Pb}$ em zircáo indicam idade mínima de cristalização de $1.314 \pm 3 \mathrm{Ma}$ para os litotipos estudados. Os dados de $\mathrm{Sm}-\mathrm{Nd}$ (rocha total) indicam uma idade modelo $\mathrm{T}_{\mathrm{DM}}$ de 1,76 Ga, considerada como indicativa de que os materiais do manto superior foram segregados para a crosta, durante o período Estateriano, no Paleoproterozoico. Finalmente, o valor negativo encontrado para $\varepsilon_{\mathrm{Nd}(\mathrm{t}=1,3)}(-14)$ é condizente com os granitos de origem crustal, sugerindo processos de fusão parcial da crosta continental na geração do magma formador do Batólito Guaporeí.

Considerando a forte foliação penetrativa com atitude preferencial N30 - 45W/65 - 80NE, correlacionável à deformação $\mathrm{D}_{3}$ (Litherland et al. 1986), a idade de $1.314 \pm 3 \mathrm{Ma}$ (Pb-Pb em zircão) de formação do Granito Guaporeí, bem como sua caracterização petrológica, sugere-se que este é correlato às intrusôes sin a tardicinemáticas do Complexo Granitoide Pensamiento, representadas pelos granitos La Junta, Puerto Alegre e San Martin (Matos et al. 2009). Conclui-se, portanto, que esses corpos são formados por um magmatismo cogenético e que as semelhanças descritas reforçam ainda mais a ideia de que a área aqui estudada é parte da continuidade crustal do Complexo Granitoide Pensamiento em território brasileiro.

O arcabouço tectônico do SW do Cráton Amazônico, particularmente no oriente boliviano e sudoeste de Mato Grosso, é caracterizado pela aglutinação de terrenos ou fragmentos crustais em diversos episódios orogênicos que culminaram com a formação do supercontinente Rodínia. Os dados geológicos, geoquímicos e isotópicos $(\mathrm{Sm}-\mathrm{Nd})$ obtidos para o Batólito Guaporeí, quando comparados aos granitoides do Complexo Pensamiento, sugerem que a intrusão investigada foi gerada em um ambiente tectônico convergente, em um arco magmático continental tipo andino, instalado às margens do Terreno Paraguá, durante a Orogenia San Ignácio.

\section{AGRADECIMENTOS}

Os autores agradecem ao PROCAD (Processo 096/2007), à FAPEMAT (Processo 002.0141/2007) e à CAPES, respectivamente, pelo custeio das análises geocronológicas/químicas e pela concessão de bolsa de mestrado à primeira autora, bem como às correçóes, sugestóes e valiosas contribuiçóes do primeiro revisor deste trabalho, Prof. Dr. Roberto Dall'Agnol. Agradecem também ao Instituto Nacional de Ciência e Tecnologia de Geociências da Amazônia (GEOCIAM) e ao Programa de Pós-graduação em Geociências da UFMT pelo suporte financeiro e logístico.

\section{REFERÊNCIAS}

Bettencourt J.S., Leite Jr. W.B., Ruiz A.S., Matos R., Payolla B.L., Tosdal R.M. 2010. The Rondonian-San Ignácio Province in the SW Amazonian Craton: an overview. Journal of South American Earth Sciences, 29(1):28-46.

Boger S.D., Raetz M., Giles D., Etchart E., Fanning C.M. 2005. U-Pb age data from the Sunsas region of Eastern Bolivia, evidence for the allochthonous origin of the Paragua Block. Precambrian Research, 139:121-146.

Debon F., Le Fort P. 1988. A cationic classification of common plutonic rocks and their magmatic associations: principles, method, applications. Bulletin de Minéralogie, 111:493-510.

DePaolo D.J. 1981. Nd isotopic studies: Some new perspectives on Earth Structure and Evolution. EOS, 62(14):137-145

Figueiredo F.L.P. 2010. Ortognaisse Turvo - registro de magmatismo paleoproterozóico no Terreno Paraguá - SW do Cráton Amazônico, Vila Bela da Santíssima Trindade, Mato Grosso. Dissertação de Mestrado, Universidade Federal de Mato Grosso, Mato Grosso, 46 p.

Figueiredo F.L.P., Ruiz A.S., Souza M.Z.A., Macambira M.J.B. 2009. Dados isotópicos $\mathrm{Pb}-\mathrm{Pb}$ em zircão do ortognaisse Turvo/
Terreno Paraguá - SW do cráton Amazônico. Boletim de Resumos Expandidos. In: Simp. 45 Anos de Geocronologia no Brasil, 2009, São Paulo - IGC-USP, p. 177-179.

Gaudette H.E., Lafon J.M., Macambira M.J.B., Moura C.A.V., Scheller T. 1998. Comparison of single filament $\mathrm{Pb}$ evaporation/ionization zircon ages with conventional U-Pb results: Examples from the Precambrian of Brazil. Journal of South American Earth Science., 11(4):351-363.

Harris N.B.W., Pearce J.A., Tindle A.G. 1986. Geochemical characteristics of collision-zone magmatism. Geological Society, London, Special Publications, 19:67-81.

Irvine T.N. \& Baragar W.R.A. 1971. A guide to the chemical classification of the common volcanic rocks. Canadian Journal of Earth Science, 8(5):523-548.

Jesus G.C., Sousa M.Z.A., Ruiz A.S., Matos J.B. 2010. Petrologia e Geocronologia (U/Pb-Sm/Nd) do Granito Passagem, Complexo Granitóide Pensamiento, SW do Cráton Amazônico (MT). Revista Brasileira de Geociências, 40(3):392-408. 
La Roche H. 1980. Granites chemistry through multicationic diagrams. Sciences de la Terre, Série Informatique Géologique, 13:65-88.

Le Bas M.J., Le Maitre R.W., Streckeisen A., Zanettin B. 1986. A chemical classification of volcanic rocks based on the total alkalisilica diagram. Journal of Petrology, 27(3):745-750.

Le Maitre R.W. 2002. Igneous Rocks: a Classification and Glossary of Terms: Recommendations of the International Union of Geological Sciences Subcommission on the Systematics of Igneous Rocks. Cambridge, Cambridge University Press, 236 p.

Litherland M., Annells R.N., Appleton J.D., Berrangé J.P., Bloomfield K., Burton C.C.J., Darbyshire D.P.F., Fletcher C.J.N., Hawkins M.P., Klinck B.A., Lanos A., Mithcell W.I., O Connor E.A., Pitfield P.E.J., Power G., Webb B.C. 1986. The Geology and Mineral Resources of the Bolivian Precambrian Shield. London, Her Majesty's Stationery Office, 140 p.

Maniar P.D. \& Piccoli P.M. 1989. Tectonic discrimination of granitoids. Geological Society of American Bulletin, 101(5):635-643.

Matos R., Teixeira W., Geraldes M.C., Bettencourt J.S. 2009. Geochemistry and Nd-Sr Isotopic Signatures of the Pensamiento Granitoid Complex, Rondonian-San Ignacio Province, East Precambrian Shield of Bolívia: Petrogenetic Constraints for a Mesoproterozoic Magmatic Arc Setting. São Paulo, Geol. USP, Sér. Cient., 9(2):89-117.

Nakamura K. 1977. Volcanoes as a possible indicator of tectonic stress orientation: principle and proposal. Journal of Volcanology Geothermal Research, 2:1-16.

Nalon P.A. 2010. O Batólito Guaporeí- uma intrusão mesoproterozóica do Complexo Granitóide Pensamiento em Mato Grosso, SW do Cráton Amazônico. Dissertação de Mestrado, Universidade Federal de Mato Grosso, Mato Grosso, 54 p.
Nalon P.A., Souza M.Z.A., Ruiz A.S. 2009. Geologia e geocronologia do Batólito Guaporeí - Suíte Intrusiva Pensamiento - Mato Grosso. Boletim de Resumos Expandidos. In: Simp. 45 Anos de Geocronologia no Brasil, 2009, São Paulo - IGC-USP, p. 277-279.

Pearce J.A., Haris N.B.W., Tindle A.G. 1984. Trace element discrimination diagrams for the tectonic interpretation of granitic rocks. Journal of Petrology, 25(4):956-983.

Peccerillo A. \& Taylor S.R. 1976. Geochemistry of Eocene calcalkaline volcanic rocks from the Kastamonu area, northern Turkey. Contributions to Mineralogy and Petrology, 58(1):63-81.

Ruiz A.S. 2009. Compartimentação Tectônica (Pré-Sunsás) do SW do Cráton Amazônico: ênfase em Mato Grosso - Brasil. In: XVIII Congresso Geológico Boliviano, Potosi, Anais.

Ruiz A.S. 2005. Evolução Geológica do Sudoeste do Cráton Amazônico Região Limítrofe Brasil-Bolívia-Mato Grosso. Tese de Doutoramento, Universidade Estadual Paulista "Julio de Mesquita Filho" - UNESP, Rio Claro, São Paulo, 260 p.

Sibson R.H. 1977. Fault rocks and fault mechanisms. Journal of the Geological Society \& London, 133(3):191-213.

Steiger R.H. \& Jäger E. 1977. Subcommission on geochronology: convention of the use of decay constants in geo- and comoschronology. Earth and Planet Science Letters, 36:359-362.

Streckeisen A. 1976. To each plutonic rock, its proper name. Earth Science Review, Amsterdam, 12(1):1-33.

Arquivo digital disponível on-line no site www.sbgeo.org.br 